Check for updates

Cite this: RSC Adv., 2019, 9, 10253

Received 15th February 2019

Accepted 14th March 2019

DOI: 10.1039/c9ra01166h

rsc.li/rsc-advances

\title{
Synthesis and biological activities of petrosiols B and $\mathrm{D} \uparrow$
}

\author{
Jialin Geng, ${ }^{\text {ab }}$ Qidong Ren, ${ }^{\text {ab }}$ Caizhu Chang, ${ }^{\text {ac }}$ Xinni Xie, ${ }^{a}$ Jun Liu (D) *ab \\ and Yuguo Du*abd
}

\begin{abstract}
A divergent total synthesis of natural diacetylenic tetraols, petrosiol B and petrosiol $\mathrm{D}$, was accomplished by taking advantage of a carbohydrate chiral template. In particular, petrosiol $\mathrm{B}$, which is the first total synthesis so far, was achieved in 13 linear steps with a 10\% overall yield applying Ohira-Bestmann homologation, $\mathrm{NaH}$-mediated dehydrobromination, and $\mathrm{Cu}(\mathrm{l})$-catalyzed Cadiot-Chodkiewicz coupling as the key reaction steps. The synthetic petrosiols $B$ and $D$ were subjected to the study on differentiation activities toward neuronal progenitor PC12 cells. Our results suggested that both petrosiol B and petrosiol D could induce the differentiation of neuronal progenitor PC12 cells via the enhancement of Nrf2 activity. By comparing petrosiols $\mathrm{B}, \mathrm{D}$ and their natural homologue $\mathrm{E}$, petrosiol $\mathrm{B}$ displayed the most intensive cell differentiation activity and the highest Nrf2 activity enhancement as well.
\end{abstract}

\section{Introduction}

Polyacetylene compounds are a class of natural product with two or more conjugated acetylenic and olefinic bonds. Not surprisingly, marine organisms have become increasingly important and thoroughly investigated sources of polyacetylenes over the past few years. ${ }^{1}$ It is believed that these polyacetylenes are biosynthetically derived from their fatty acid progenitors via desaturase-promoted dehydrogenation, leading to double bonds at specific sites of the carbon chain in normally high $Z$-selectivity. ${ }^{2}$ Further dehydrogenation of some double bonds in the presence of acetylenases generates alkynes which play crucial roles in their biological activities. ${ }^{1 a}$ Results from human nutrition research reveals that some of the polyacetylene compounds exhibit health chemopreventive effects, while some of their structural analogues are toxins with strong neurotoxicity. ${ }^{3,4}$ Due to their unique structural characteristics and impressive pharmacological properties such as antiinflammatory, antimicrobial, antitumor, antiviral and neuritogenic activities, polyacetylenes have attracted significant interest in terms of the isolation, structure determination,

${ }^{a}$ State Key Laboratory of Environmental Chemistry and Eco-Toxicology, Research Center for Eco-Environmental Sciences, Chinese Academy of Science, Beijing 100085, China.E-mail: junliu@rcees.ac.cn

${ }^{b}$ School of Chemical Sciences, University of Chinese Academy of Sciences, Beijing 100049, China

'School of Chemistry and Environmental Engineering, Wuhan Institute of Technology, Wuhan 430205, China

${ }^{d}$ National Engineering Research Center for Carbohydrate Synthesis, Jiangxi Normal University, Nanchang 330022, China

$\dagger$ Electronic supplementary information (ESI) available. See DOI: $10.1039 / \mathrm{c} 9 \mathrm{ra01166h}$ bioactivity screening, and synthetic attempt. ${ }^{1}$ Recent examples of this polyacetylene family include debilisones $\mathrm{A}-\mathrm{F},{ }^{5}$ strongylodiols A-I, ${ }^{6}$ ivorenolide $\mathrm{A}-\mathrm{B},{ }^{7}$ and atractylodemaynes A-G. ${ }^{8}$

Petrosiols A-E (1-5) (Fig. 1) are polyacetylene-containing natural products isolated from the Okinawan marine sponge Petrosia strongylata by Ojika's group in $2013 .{ }^{9}$ The structure and absolute stereochemistry of the petrosiols was determined by derivatization of petrosiol $\mathrm{C}$ and a modified Mosher's method as well, sharing a common structural feature of unusual triynetriyne inserted tetraol skeleton with different side chain residues.

Because of their novel structure feature, impressive broadband biological activities, and most importantly the limited availability, petrosiols have attracted the attention toward the total synthesis. Srihari and co-workers reported the first total synthesis of petrosiol D using (+)-diethyl L-tartrate as starting material and Cadiot-Chodkiewicz coupling as the key step in $2013 .^{10}$ The same group also reported the total synthesis of petrosiols A and E using a similar strategy in $2016 .{ }^{11}$ As part of our interests in the total synthesis of various complex natural products based on carbohydrate skeletons, we have reported the first total synthesis of petrosiol E from D-xylose in $2014 .^{12}$ So far, there is no report regarding the syntheses of petrosiols B and C.

With the synthetic petrosiol $\mathrm{E}$ in hand, we studied its molecular mechanism in stimulating neuronal differentiation and antioxidative stress in PC12 neuronal progenitor cells. ${ }^{13} \mathrm{We}$ found that petrosiol $\mathrm{E}$ could stimulate the mitogen-activated protein kinase and serine/tyrosine kinase signaling to enhance the activity of Nrf2. We also identified a dual role of petrosiol $\mathrm{E}$ in potentiating the differentiation of neuronal progenitors and in protecting them against arsenic-induced oxidative stress in PC12 cells. The impressive biological activity and the lack of structure-activity relationship (SAR) 
<smiles>CCCCCCCC/C=C/CCCCCCC[C@@H](O)[C@@H](O)[C@H](O)C#CC#CC(C)O</smiles>

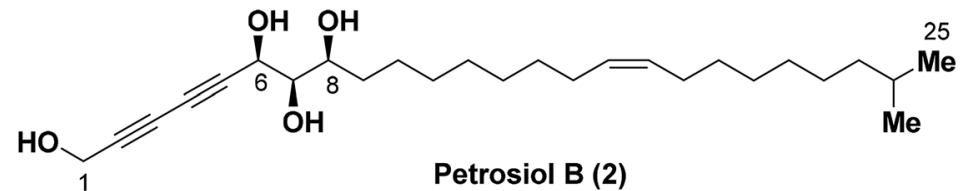<smiles>C#C/C=C\CCCCCCCCCC/C=C/CCCCCCC[C@@H](O)[C@@H](O)[C@H](O)C#CC#CC(O)I</smiles><smiles>CCCCCCCCC/C=C/CCCCCCC[C@@H](O)[C@@H](O)[C@H](O)C#CC#CCO</smiles><smiles>CCOC(=O)C#CC#C[C@@H](O)[C@@H](O)[C@H](O)CCCCCCCCCCCCCC(C)C</smiles>

Fig. 1 Structures of petrosiols A-E (1-5).

studies on petrosiols encouraged us to undertake a flexible and scalable synthesis of these novel natural products. Herein, we disclose the first total synthesis of petrosiol B and total synthesis of petrosiol D using readily available carbohydrate $\mathrm{D}^{-}$ mannose as the chiral pool.

\section{Results and discussion}

Based on the results from our previous biological study, ${ }^{13}$ petrosiols could induce nerve growth factor (NGF)-like neuronal differentiation of PC12 cells in a dose-dependent manner. It thus could provide a potential agent for the prevention and treatment of neurodegenerative diseases such as Parkinson's disease (PD) and Alzheimer disease (AD). In this regard, it is highly demanding a method to reach the common crucial tetraol skeleton of petrosiols in an efficient and easy scaling up way, although we have realized that the structure sensitivity toward oxidation and light makes them challenging synthetic target molecules.

Our retrosynthetic analysis for the total syntheses of petrosiols B and D is presented in Scheme 1.

Accordingly, a divergent approach was designed taking advantage of the same triyne-triyne tetraol framework (C1-C17) which can be accessed by coupling of the precursor bromoalkyne 6 with propargyl alcohol via Cadiot-Chodkiewicz reaction for both petrosiol $\mathrm{B}$ and petrosiol $\mathrm{D}$. The requisite precursor 6 could be generated from the primary alcohol 7 followed by functional group transformation via sequential alkylation of the terminal alkyne, Lindlar catalyst promoted cisreduction, acetonide cleavage, and Corey-Fuchs reaction. As for the key intermediate 7 , it could be obtained by coupling of bromide 9 and hemiacetal 8 via a multi-step sequential modification. Details of the studies thus undertaken are described below.

The synthetic sequence commenced with the formation of the terminal alkyne 10 from commercially available 2,3:5,6-di-Oisopropylidene- $\alpha$-D-mannofuranose (8) as the starting material following a modified procedure from Lievre's report (Scheme 2). ${ }^{14}$ We thought that a total synthesis of the target petrosiols from a chiral carbohydrate material with a reliably assigned absolute configuration might substantiate the reported structural assignment. Thus, the masked carbonyl group of hemiacetal 8 was converted into the corresponding terminal alkyne by addition of Ohira-Bestmann reagent and $\mathrm{K}_{2} \mathrm{CO}_{3}$ in refluxing methanol. ${ }^{15,16}$ The desired epimerization at the propargylic stereocenter (C-5) occurred smoothly and confirmed by an upfield shifting of $\mathrm{H} 5$ signal $(4.66 \mathrm{ppm}, J=7.6,2.0 \mathrm{~Hz}){ }^{14}$ The full inversion of stereocenter could be attributed to the greater thermodynamic stability of the trans over the cis C4-C5 acetonide structure. ${ }^{16}$

To differentiate the secondary alcohol of $\mathbf{1 0}$ from its latent primary alkyl hydroxyl group introduced later, alkyne $\mathbf{1 0}$ was exposed to excess $\mathrm{MOMCl}$ in dichloromethane at $\mathrm{rt}$ for $48 \mathrm{~h}$ with DIPEA as the base. However, the MOM-protected product $\mathbf{1 1}$ was isolated in only $10 \%$ yield together with $71 \%$ of recovered 

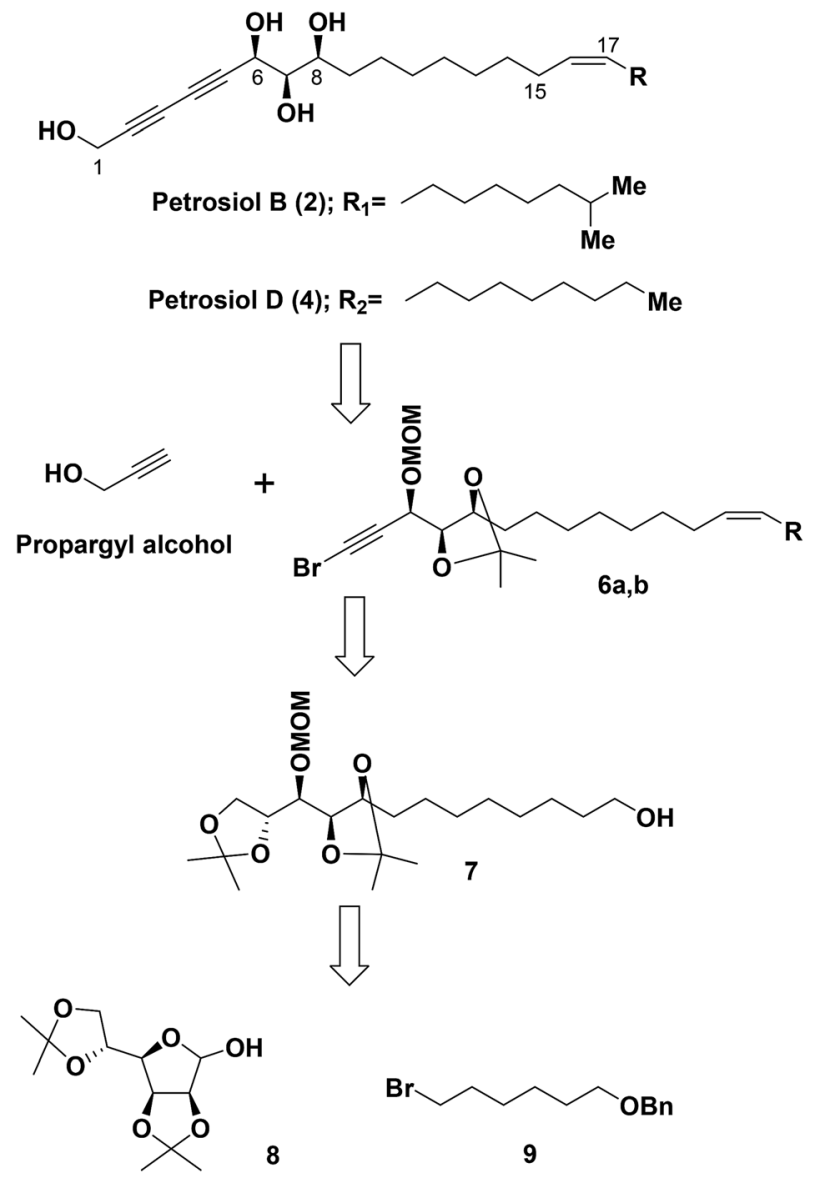

Scheme 1 Retrosynthetic analysis of petrosiols B and D.

10. Attempts to improve the yield of this protection by changing solvents or elevating reaction temperature were fruitless (Table 1, entries 1-4). Other attempts to protect the secondary alcohol using TBDPS as protection group also failed (entries 5-6). Using stronger base such as DMAP or NaH did not improve the reaction yield at all. To our surprise, the desired MOM-protected product 11 was eventually obtained in 93\% yield in the presence of $\mathrm{NaH}$ in THF containing two drops of water at room temperature (entry 8). After reviewing the literature, we recognize that catalytic amounts of water and $\mathrm{NaH}$ produce highly active $\mathrm{NaOH}$, which is the real base to promote the reaction. ${ }^{\mathbf{1 7}}$ We assumed that the exothermic process when adding water into the reaction mixture also facilitated the reaction in some extent. $^{18}$

Terminal alkyne $\mathbf{1 1}$ was then alkylated with bromide $\mathbf{9}$ in the presence of HMPA leading to the desired alkyne $\mathbf{1 2}$ in a yield of $83 \%$. Hydrogenation of $\mathbf{1 2}$ in methanol/ethyl acetate removed benzyl group and saturated the triple bond at the same time gave 7 in excellent yield. The primary alcohol 7 was oxidized to the corresponding aldehyde by Dess-Martin oxidation ${ }^{\mathbf{1 9}}$ and the crude aldehyde was used directly for the Ohira-Bestmann homologation $^{20}$ afforded 13 in 70\% yield over two steps.

Alkylation of the terminal alkyne 13 with iodoalkanes afforded compounds 14a,b, corresponding to petrosiols B and D respectively, in good yields (Scheme 3). Partial hydrogenation of 14a,b with Lindlar catalyst ( $5 \% \mathrm{Pd}$ on $\mathrm{CaCO}_{3}$ poisoned with lead) under $\mathrm{H}_{2}$ atmosphere afforded the cis-olefins 15a,b with excellent $Z / E$ selectivity $(>20: 1)$. Regioselective oxidative cleavage of the terminal isopropylidene group in $\mathbf{1 5 a}, \mathbf{b}$ was performed with periodic acid in dry ethyl acetate affording one-carbon diminished aldehyde, ${ }^{20}$ which was immediately treated with $\mathrm{CBr}_{4} / \mathrm{PPh}_{3}$ in $\mathrm{DCM}^{\mathbf{2 1 , 2 2}}$ to generate 1,L-dibromoalkenes 16a,b in about 51$52 \%$ yield. NaH-mediated dehydrobromination ${ }^{12,23}$ of dibromoalkenes in wet THF at room temperature provided monobromoalkynes $\mathbf{6 a}, \mathbf{b}$ in excellent yield. $\mathrm{Cu}(\mathrm{I})$-catalyzed CadiotChodkiewicz cross coupling of propargyl alcohol with monobromoalkynes $\mathbf{6 a} \mathbf{a} \mathbf{b}$ afforded the corresponding diynes $\mathbf{1 7 a , \mathbf { b } ^ { 2 4 }}$ Finally, one-pot global deprotection of $\mathbf{1 7 a}, \mathbf{b}$ were achieved with

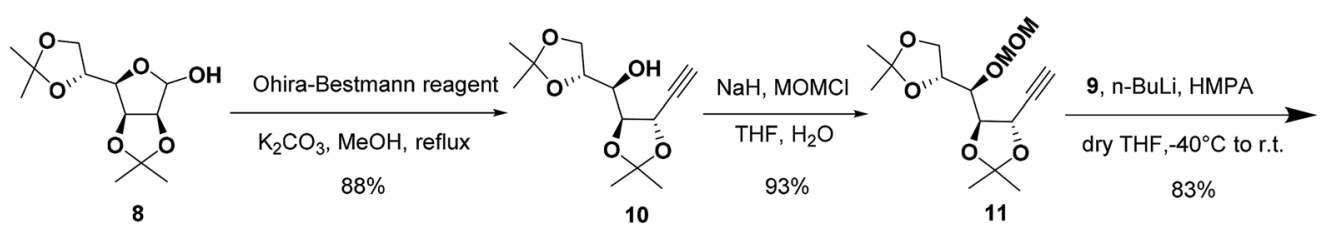

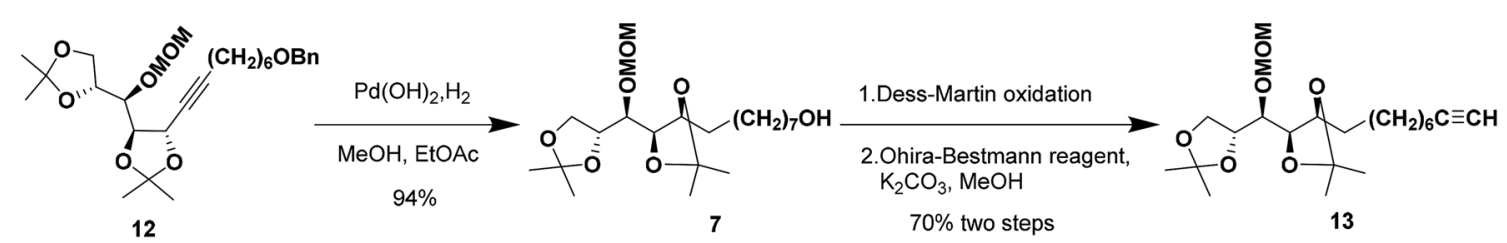<smiles>CC(=O)C(=[N+]=[N-])C(=O)O</smiles>

Ohira-Bestmann reagent<smiles>BrCCCCCCOCc1ccccc1</smiles><smiles>CC(=O)O[Te]1(O)(OC(C)=O)OC(=O)c2ccccc21</smiles>

Dess-Martin reagent

Scheme 2 Synthesis of the C5-C16 fragment. 
Table 1 Optimization of the reaction conditions

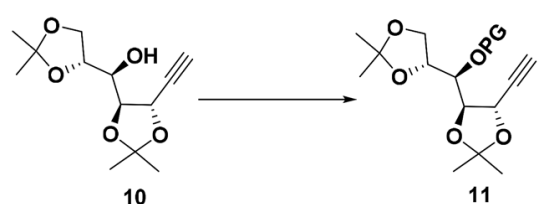

\begin{tabular}{|c|c|c|c|c|c|}
\hline Entry & Conditions & Solvent & $T\left({ }^{\circ} \mathrm{C}\right)$ & Time (h) & Yield (\%) \\
\hline 1 & MOMCl (2 eq.), DIPEA (3 eq.) & DCM & 20 & 48 & $<10$ \\
\hline 2 & MOMCl ( 5 eq.), DIPEA (3 eq.) & DCM & Reflux & 48 & 18 \\
\hline 3 & $\operatorname{MOMCl}(2$ eq.), DIPEA ( 3 eq.), DMAP (cat) & THF & 20 & 48 & $<10$ \\
\hline 4 & $\operatorname{MOMCl}(2$ eq.), DIPEA ( 3 eq.), DMAP (cat) & DCM & Reflux & 48 & 20 \\
\hline 5 & TBDPSCl (1.5 eq.), imidazole ( 4 eq.) & DMF & 20 & 48 & $<5$ \\
\hline 6 & TBDPSCl (3 eq.), imidazole (4 eq.) & DMF & 80 & 48 & $<5$ \\
\hline 7 & MOMCl (3 eq.), $\mathrm{NaH}$ (5 eq.) & THF & 20 & 7 & $<5$ \\
\hline 8 & MOMCl (3 eq.), NaH (5 eq.), with few drops of water & THF & 20 & 5 & 93 \\
\hline
\end{tabular}

$3 \mathrm{~N} \mathrm{HCl}$ in refluxing ethanol, delivering petrosiol B (2) in $97 \%$ yield and petrosiol D (4) in 98\% yield, respectively. The spectroscopic data $\left({ }^{1} \mathrm{H},{ }^{13} \mathrm{C}\right.$ NMR, and HRMS $)$ and specific rotation data of both synthetic petrosiol $\mathrm{B}$ and petrosiol $\mathrm{D}$ were in good agreement with those of the natural products (see the $\mathrm{ESI}_{\dagger}^{\dagger}$ ).

\section{Bioactivity section}

Biological activity of the synthetic petrosiols B and D were investigated following our previous evidences on homologue $\mathrm{E}$ induced PC12 cells differentiation. ${ }^{13}$ To find out the feasible concentrations in differentiation experiment, petrosiols<smiles>[CH]O[C@@H](C1OC(C)(CCCC#C)C(C)(C)[C@@H]1O)[C@H]1COC(C)(C)O1</smiles>

13

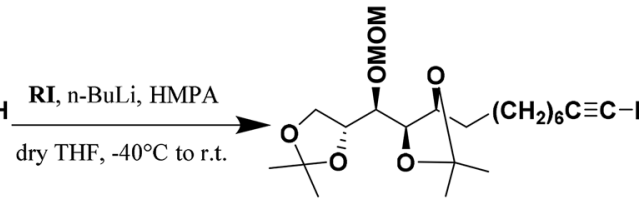

14a: $\mathrm{R}=\left(\mathrm{CH}_{2}\right)_{6} \mathrm{CH}\left(\mathrm{CH}_{3}\right)_{2} ; 70 \%$

14b: $\mathrm{R}=\left(\mathrm{CH}_{2}\right)_{8} \mathrm{CH}_{3} ; 75 \%$<smiles>[R]C1CCCC1CCC</smiles>

15b: $\mathrm{R}=\left(\mathrm{CH}_{2}\right)_{8} \mathrm{CH}_{3} ; 99 \%$

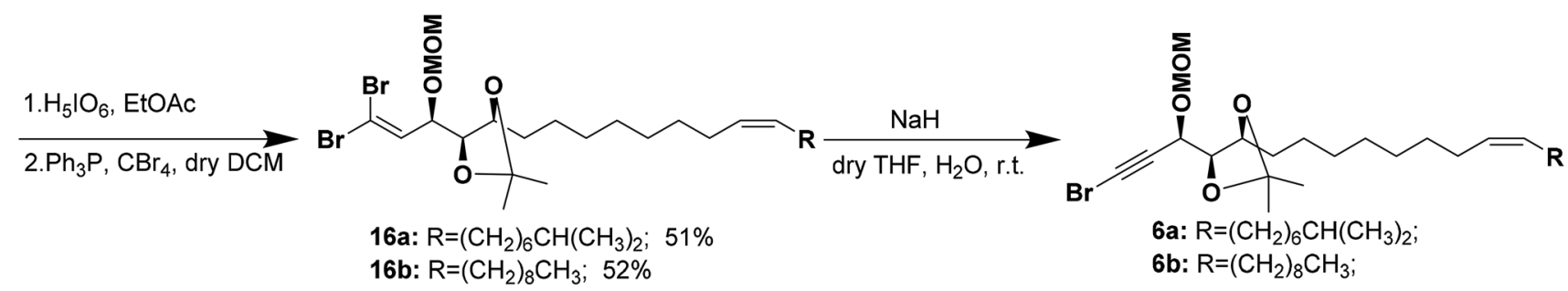

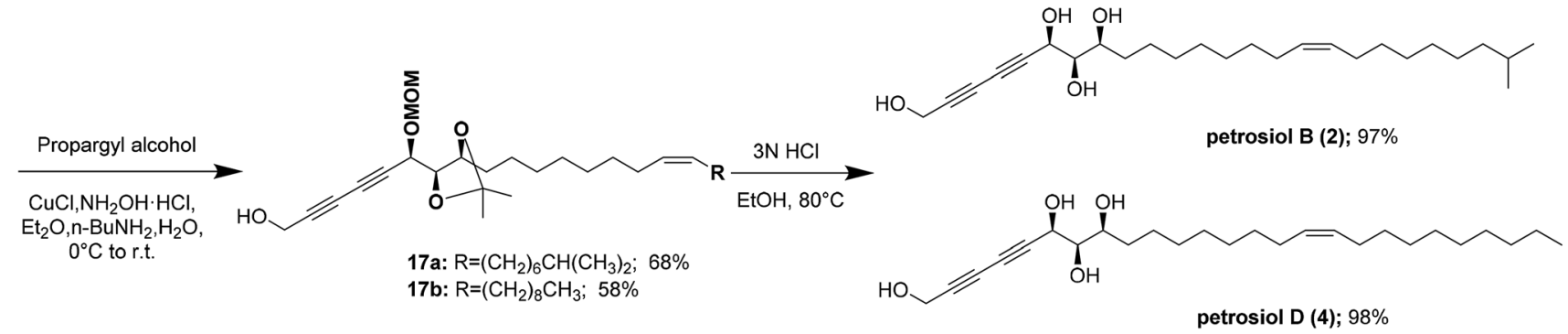

Scheme 3 Total synthesis of petrosiols B and D. 
(A)

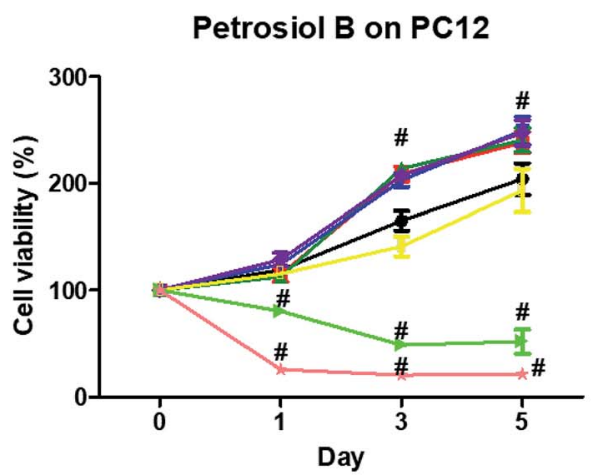

(B)

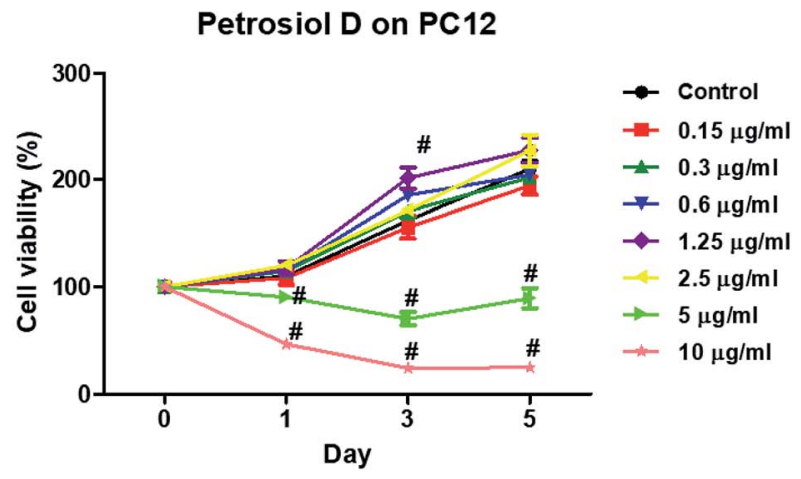

Fig. 2 Screening of sub-lethal concentrations of petrosiols $B(A)$ and $D(B)$ on $P C 12$ cells. Cell viability was determined through $C C K-8$ assay at different concentrations of petrosiols B and D for 1,3 , and $5 \mathrm{~d}$. ${ }^{\#} P<0.001$, relative to untreated control.

(A)

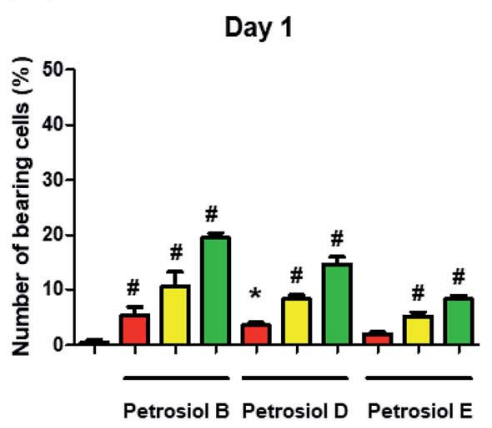

(B)

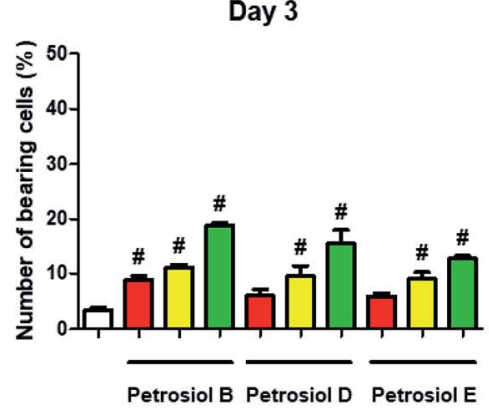

(C)

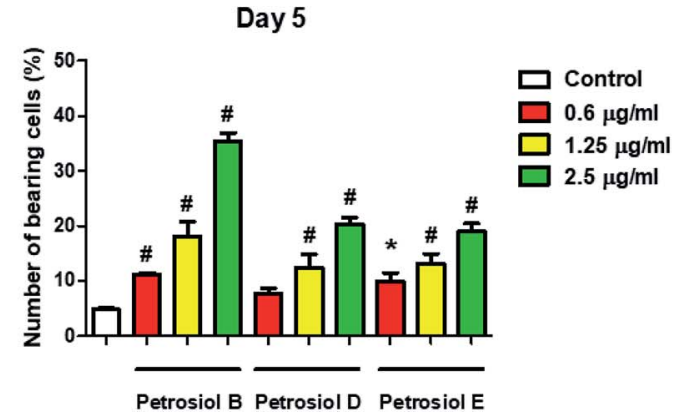

Fig. 3 Petrosiols $B$ and D promoted neurite outgrowth and activity of Nrf2 in PC12 cells. Petrosiol B, D and E promoted neurite outgrowth in PC12 cells on day 1 (A), 3 (B), and 5 (C). ${ }^{*} P<0.05$, relative to control. ${ }^{*} P<0.001$, relative to control.

ranging from $0.15 \mu \mathrm{g} \mathrm{mL} \mathrm{m}^{-1}$ to $10 \mu \mathrm{g} \mathrm{mL}^{-1}$ were subjected to PC12 cell to evaluate the cell viability using the Cell Counting Kit-8 (CCK-8). As shown in Fig. 2, petrosiol displayed no obvious effects on cell viability from day 1 to day 5 when the cell was treated with petrosiol (B/D) below the concentration of $5 \mu \mathrm{g}$ $\mathrm{mL}^{-1}$. In particular, petrosiol B inhibited PC12 cell viability by about $74 \%(P<0.001)$ after 1 day treatment and further repressed by about $80 \%(P<0.001)$ after 5 day treatment at $10 \mu \mathrm{g}$ $\mathrm{mL}^{-1}$ (Fig. 2A), while petrosiol $\mathrm{D}$ inhibited cell viability by about $54 \%(P<0.001)$ after 1 day and about $75 \%(P<0.001)$ after 5 day at $10 \mu \mathrm{g} \mathrm{mL} \mathrm{m}^{-1}$ (Fig. 2B). Therefore, concentrations lower than 5 $\mu \mathrm{g} \mathrm{mL}^{-1}$ were chosen for the synthetic petrosiols in the following biological experiments.

To evaluate the effect of petrosiol on neuronal progenitors differentiation, PC12 cells were treated with petrosiols at different concentrations and under varying exposure time. As shown in Fig. 3 and 4, treatment of PC12 cells with petrosiols $\mathrm{B}, \mathrm{D}$ and $\mathrm{E}$ all significantly increased the number of neurites in cells in a dose- and time-dependent manner compared to control treatment, and petrosiol B showed strongest activity on neuronal differentiation. Specifically on day 5 at $2.5 \mu \mathrm{g}$ $\mathrm{mL}^{-1}$, petrosiol B induced about $35 \%(P<0.001)$ of cells generating neurite outgrowth, while $20 \%(P<0.001)$ petrosiol
D, 19\% $(P<0.001)$ for petrosiol $\mathrm{E}$ under the same incubation conditions (Fig. 3C). Interestingly, petrosiols D and E induced a comparative differentiating cells on day 5 (Fig. 3C) though D showed stronger inducing effect than E on day 1 and 3 (Fig. 3A and $\mathrm{B})$. The current result suggested that petrosiol compounds triggered neuronal differentiation of PC12 cells, though petrosiol B exhibited stronger effect than its homologues D and E.

We also investigated the molecular mechanism concealing the petrosiol-induced neuronal differentiation. Our previous study indicated that petrosiol E induced PC12 differentiation by enhancing the activity of Nrf2 which is indispensable in an augmented differentiation process. We thus explored Nrf2 activity of PC12 cells in the presence of petrosiols B and D by detecting the contents of Nrf2 protein in nucleus, respectively. As shown in Fig. 5, petrosiols (at 1.25 and $2.5 \mu \mathrm{g} \mathrm{mL}^{-1}$ ) significantly upregulated the contents of Nrf2 in nuclear portion after treatment for $24 \mathrm{~h}$, relative to untreated control cells. After $24 \mathrm{~h}$ treatment with petrosiols B, D and E at $2.5 \mu \mathrm{g} \mathrm{mL}^{-1}$, the nuclear Nrf2 level was increased by $3.5-(P<0.001), 3.7-(P<0.001)$ and 2.6-fold $(P<0.05)$ compared to the untreated control (Fig. 5B), respectively. To further confirm the petrosiols induced Nrf2 activation, downstream target gene heme oxygenase-1 (HO-1) ${ }^{25}$ 


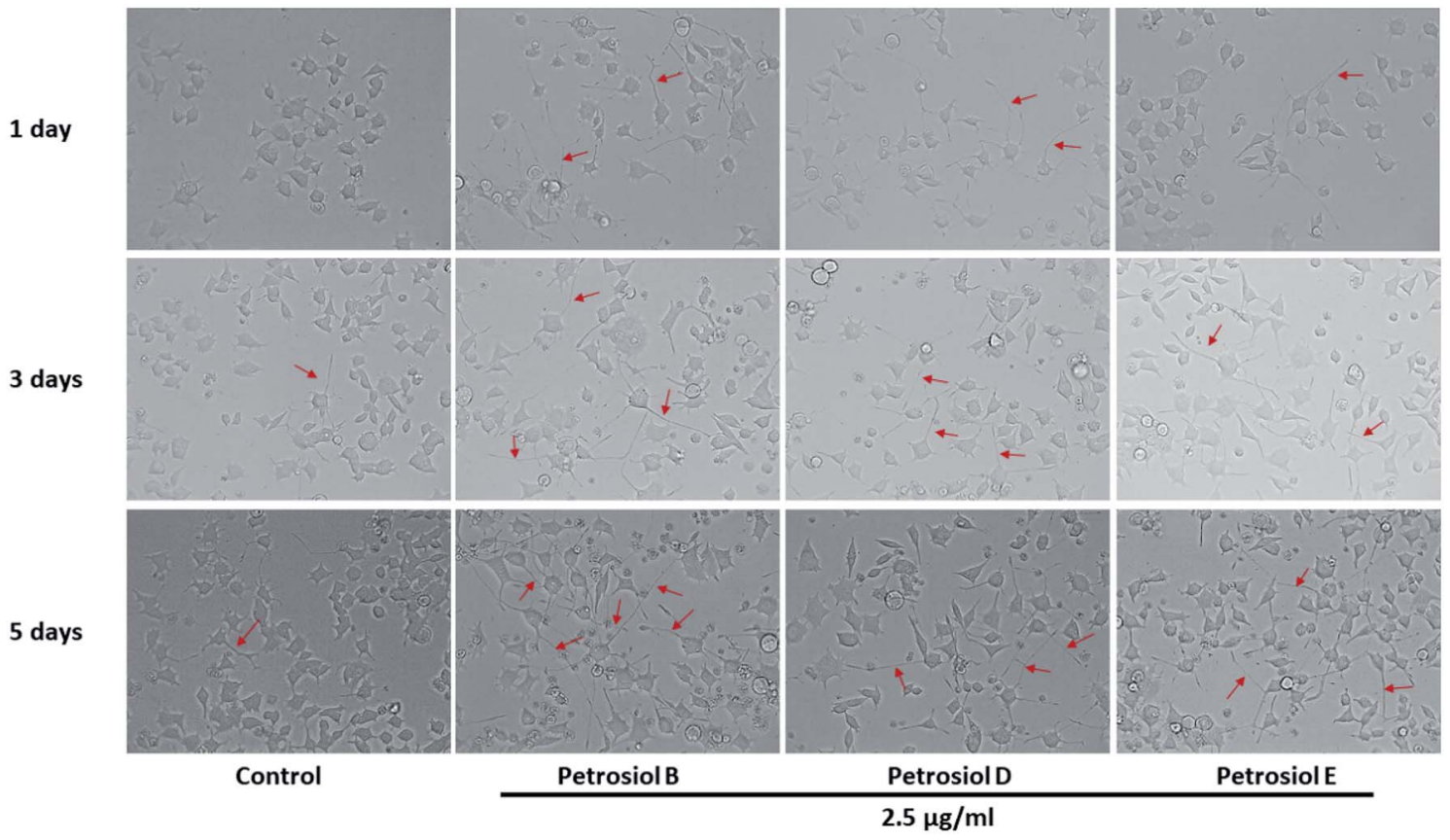

Fig. 4 The morphology changes of PC12 cells after petrosiols B, D, and E induction at $2.5 \mu \mathrm{mL}^{-1}$ at day 3 and day 5 .

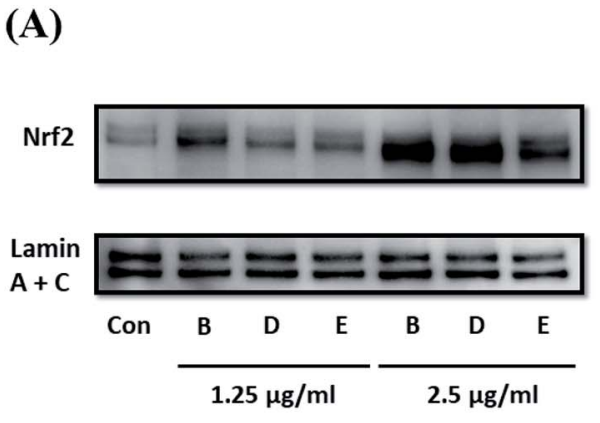

(B)

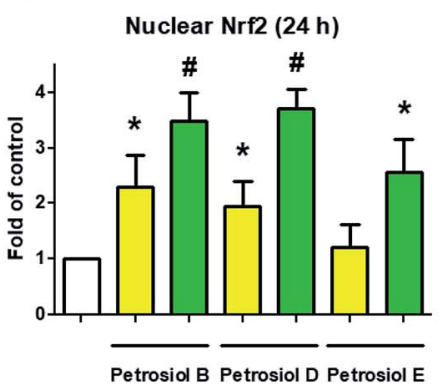

(C)

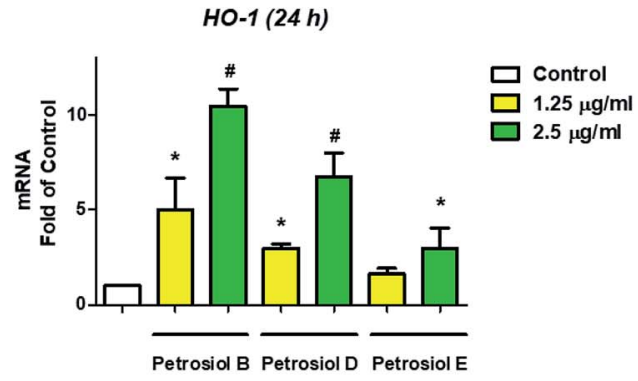

Fig. 5 Petrosiols upregulated Nrf2 protein level in nuclear. (A) Protein levels in PC12 cell nuclear were determined via western blot. (B) Quantitative analysis of Nrf2 protein abundance was conducted with ImageJ software. Lamin A + C served as loading control. (C) The mRNA levels of HO-1 expression upon various concentrations of petrosiols $\mathrm{B}, \mathrm{D}$ and $\mathrm{E}$ for $24 \mathrm{~h}$. ${ }^{*} P<0.05$, relative to control. ${ }^{\#} P<0.001$, relative to control.

of Nrf2 was also checked at mRNA level upon petrosiol exposure. It was found that petrosiols $\mathrm{B}, \mathrm{D}$ and $\mathrm{E}$ at $2.5 \mu \mathrm{g} \mathrm{mL}^{-1}$ increased mRNA level of HO-1 by 10.4- $(P<0.001)$, 6.7- $(P<$ $0.001)$ and 2.9 -fold $(P<0.05)$ relative to the untreated control, respectively, which were consistent with the enhancement of nuclear Nrf2 protein (Fig. 5C). These findings strongly indicated that petrosiols could enhance neuronal differentiation through activating Nrf2.

\section{Conclusions}

In conclusion, we have achieved the first total synthesis of petrosiol B and a total synthesis of petrosiol D at the same time using readily available carbohydrate $\mathrm{D}$-mannose as the chiral template. The synthetic petrosiols (B, D and E) were found to elicit the differentiation of neuronal progenitor PC12 cells through an enhanced Nrf2 activity in cell nuclear. Among them, petrosiol B presented the best potential in this regards. Further efforts for the divergent syntheses and SAR studies of other petrosiol-derived polyacetylenes ${ }^{1,26}$ are currently underway in our laboratory.

\section{Experimental}

\section{General methods}

Unless noted otherwise, commercially available materials were used without further purification. Yields refer to chromatographically and spectroscopically $\left({ }^{1} \mathrm{H}\right.$ NMR) homogeneous materials. All solvents were dried according to the established procedures ahead of use. Flash chromatography (FC) was performed using silica gel (200-300 meshes) according to the standard protocol. All reactions under standard conditions were monitored by thin-layer chromatography (TLC) on gel 
F254 plates. Optical rotations were measured using a polarimeter with a thermally jacketed $2.5 \mathrm{~cm}$ cell at approximately $25{ }^{\circ} \mathrm{C}$. High-resolution mass spectrometry data (HRMS) were acquired using a Q-TOF analyzer in methanol as solvent. ${ }^{1} \mathrm{H}$ NMR, ${ }^{13} \mathrm{C}$ NMR were measured on $400 \mathrm{MHz}$ or $100 \mathrm{MHz}$ spectrometers. Chemicals shifts $(\delta)$ were expressed in ppm relative to residual $\mathrm{CHCl}_{3}, \mathrm{CD}_{3} \mathrm{OD}$ or TMS. Multiplicity is tabulated as $\mathrm{s}$ for singlet, $\mathrm{d}$ for doublet, $\mathrm{t}$ for triplet, $\mathrm{q}$ for quadruplet, and $\mathrm{m}$ for multiplet and br when the signal in question is broadened.

\section{Synthesis of compound 10}

$\mathrm{MeOH}(10 \mathrm{~mL})$ was added to a mixture of $8(3.0 \mathrm{~g}, 11.5 \mathrm{mmol})$ and $\mathrm{K}_{2} \mathrm{CO}_{3}(4.0 \mathrm{~g}, 28.9 \mathrm{mmol})$. The mixture was stirred under an argon atmosphere and allowed to reflux. Dimethyl(1-diazo-2oxopropyl)phosphonate $(4.33 \mathrm{~mL}, 28.8 \mathrm{mmol})$ was added dropwise within $6 \mathrm{~h}$, at the end of which time the mixture was cooled to room temperature, then it was filtered on glass-frit and concentrated. After an extraction with EtOAc $/ \mathrm{H}_{2} \mathrm{O}$, the combined organic extracts was dried over $\mathrm{Na}_{2} \mathrm{SO}_{4}$ and concentrated. The crude residue was purified by flash chromatography (petroleum ether/EtOAc $4: 1$ ) to afford 10 as a syrup. Yield: $2.6 \mathrm{~g}$ (88\%): $[\alpha]_{\mathrm{D}}^{28}=-25.7\left(c 1.4, \mathrm{CHCl}_{3}\right) ;{ }^{1} \mathrm{H}$ NMR (400 $\mathrm{MHz}, \mathrm{CDCl}_{3}$ ) $\delta 4.66(\mathrm{dd}, J=7.6,2.0 \mathrm{~Hz}, 1 \mathrm{H}), 4.28$ (d, $J=7.6 \mathrm{~Hz}, 1 \mathrm{H}), 4.13-3.98$ $(\mathrm{m}, 3 \mathrm{H}), 3.56(\mathrm{dd}, J=7.4,2.3 \mathrm{~Hz}, 1 \mathrm{H}), 2.54(\mathrm{~d}, J=2.1 \mathrm{~Hz}, 1 \mathrm{H})$, $1.51(\mathrm{~s}, 3 \mathrm{H}), 1.43$ (d, $J=2.5 \mathrm{~Hz}, 6 \mathrm{H}), 1.36$ (s, 3H); ${ }^{13} \mathrm{C}$ NMR $(100$ $\left.\mathrm{MHz}, \mathrm{CDCl}_{3}\right) \delta 111.2,109.7,81.0,80.7,76.3,75.1,70.0,67.0$, 66.8, 27.0, 26.8, 26.3, 25.5; HRMS (ESI): calcd. for $\mathrm{C}_{13} \mathrm{H}_{20} \mathrm{O}_{5} \mathrm{~K}^{+}$ $[\mathrm{M}+\mathrm{K}]^{+}, 295.0942$; found 295.0983 . The ${ }^{1} \mathrm{H}$ and ${ }^{13} \mathrm{C} \mathrm{NMR}$ spectra were identical to those reported in ref. 14 .

\section{Synthesis of compound 11}

To a stirred solution of $10(889 \mathrm{mg}, 3.47 \mathrm{mmol})$ in dry THF (50 $\mathrm{mL}$ ) were added $\mathrm{NaH}$ (694 $\mathrm{mg}, 17.4 \mathrm{mmol}$ ) and methoxymethyl chloride ( $0.79 \mathrm{~mL}, 10.4 \mathrm{mmol})$. After $5 \mathrm{~min}$, deionized water (50 $\mu \mathrm{L}$ ) was added slowly into the mixture via syringe at room temperature and it will be exothermic. The reaction mixture was stirred for $5 \mathrm{~h}$ and quenched with saturated $\mathrm{NH}_{4} \mathrm{Cl}$ aqueous solution. The organic phase in the resulting solution mixture was extracted with EtOAc ( 3 times, $50 \mathrm{~mL}$ each), dried over $\mathrm{Na}_{2} \mathrm{SO}_{4}$, filtered, and finally evaporated under a reduced pressure. The residue was purified by chromatography on silica gel (petroleum ether/EtOAc $7: 1$ ) to afford 11 as a colorless oil. Yield: $967 \mathrm{mg}$ (93\%): $[\alpha]_{\mathrm{D}}^{25}=-25.0\left(c 2.1, \mathrm{CHCl}_{3}\right) ;{ }^{1} \mathrm{H}$ NMR (400 MHz, $\mathrm{CDCl}_{3}$ ) $\delta 4.83(\mathrm{~d}, J=6.8 \mathrm{~Hz}, 1 \mathrm{H}), 4.74(\mathrm{~d}, J=6.7 \mathrm{~Hz}, 1 \mathrm{H}), 4.65(\mathrm{dd}, J=7.5$, $2.0 \mathrm{~Hz}, 1 \mathrm{H}), 4.24-4.17(\mathrm{~m}, 1 \mathrm{H}), 4.15$ (dd, $J=7.5,3.7 \mathrm{~Hz}, 1 \mathrm{H}), 4.09-$ $3.99(\mathrm{~m}, 2 \mathrm{H}), 3.85(\mathrm{t}, J=4.3 \mathrm{~Hz}, 1 \mathrm{H}), 3.42(\mathrm{~s}, 3 \mathrm{H}), 2.54(\mathrm{~d}, J=$ $2.0 \mathrm{~Hz}, 1 \mathrm{H}), 1.48(\mathrm{~s}, 3 \mathrm{H}), 1.42(\mathrm{~d}, J=3.0 \mathrm{~Hz}, 6 \mathrm{H}), 1.36(\mathrm{~s}, 3 \mathrm{H}) ;{ }^{13} \mathrm{C}$ $\mathrm{NMR}\left(100 \mathrm{MHz}, \mathrm{CDCl}_{3}\right) \delta 110.9,109.0,98.3,82.2,81.0,76.7,75.8$, 74.9, 66.8, 65.8, 56.4, 26.7, 26.6, 26.4, 25.5; HRMS (ESI): calcd. for $\mathrm{C}_{15} \mathrm{H}_{24} \mathrm{O}_{6} \mathrm{Na}^{+}[\mathrm{M}+\mathrm{Na}]^{+}$, 323.1465; found 323.1457.

\section{Synthesis of compound 12}

$n$-Butyllithium (2.5 $\mathrm{M}$ in hexanes, $1.33 \mathrm{~mL}, 3.32 \mathrm{mmol}$ ) was added dropwise to a stirred solution of terminal alkyne $\mathbf{1 1}$ (830 $\mathrm{mg}, 2.77 \mathrm{mmol}$ ) and HMPA (0.73 mL, $4.15 \mathrm{mmol}$ ) in dry
THF $(30 \mathrm{~mL})$ at $-40{ }^{\circ} \mathrm{C}$. The reaction mixture was stirred at $-40{ }^{\circ} \mathrm{C}$ for 20 minutes, then added 9 gave an orange colored solution. The reaction mixture was stirred at room temperature overnight and quenched with saturated $\mathrm{NH}_{4} \mathrm{Cl}$ aqueous solution. The organic phase in the resulting solution mixture was extracted with EtOAc ( 3 times, $50 \mathrm{~mL}$ each), dried over $\mathrm{Na}_{2} \mathrm{SO}_{4}$, filtered, and finally evaporated under a reduced pressure. The residue was purified by chromatography on silica gel (petroleum ether/EtOAc $7: 1)$ to afford 12 as a colorless oil. Yield: $967 \mathrm{mg}(83 \%):[\alpha]_{\mathrm{D}}^{25}=-21.6\left(c 0.4, \mathrm{CHCl}_{3}\right) ;{ }^{1} \mathrm{H}$ NMR $(400 \mathrm{MHz}$, $\left.\mathrm{CDCl}_{3}\right) \delta 7.36-7.26(\mathrm{~m}, 5 \mathrm{H}), 4.84(\mathrm{~d}, J=6.6 \mathrm{~Hz}, 1 \mathrm{H}), 4.73(\mathrm{~d}, J=$ $6.6 \mathrm{~Hz}, 1 \mathrm{H}), 4.60(\mathrm{dt}, J=7.7,1.9 \mathrm{~Hz}, 1 \mathrm{H}), 4.49(\mathrm{~s}, 2 \mathrm{H}), 4.24-4.16$ $(\mathrm{m}, 1 \mathrm{H}), 4.06-3.97(\mathrm{~m}, 3 \mathrm{H}), 3.86(\mathrm{t}, J=4.0 \mathrm{~Hz}, 1 \mathrm{H}), 3.45(\mathrm{t}, J=$ $6.6 \mathrm{~Hz}, 2 \mathrm{H}), 3.41(\mathrm{~s}, 3 \mathrm{H}), 2.21(\mathrm{td}, J=7.1,1.9 \mathrm{~Hz}, 2 \mathrm{H}), 1.65-1.57$ (m, 2H), 1.56-1.44 (m, 5H), 1.43-1.34 (m, 13H); ${ }^{13} \mathrm{C}$ NMR (100 $\left.\mathrm{MHz}, \mathrm{CDCl}_{3}\right) \delta 138.8,128.5,127.8,127.7,110.2,108.9$, 98.2, 87.9, 82.2, 76.8, 76.6, 75.3, 73.1, 70.5, 67.4, 65.6, 56.4, 29.8, 28.9, 28.6, 26.8, 26.7, 26.6, 25.9, 25.5, 18.9; HRMS (ESI): calcd. for $\mathrm{C}_{28} \mathrm{H}_{43} \mathrm{O}_{7}^{+}[\mathrm{M}+\mathrm{H}]^{+}, 491.3003$, found 491.3004 .

\section{Synthesis of compound 7}

To a solution of $12(900 \mathrm{mg}, 1.83 \mathrm{mmol})$ in $30 \mathrm{~mL}$ of methanol and ethyl acetate $(\mathrm{v} / \mathrm{v}=1: 2)$ was added palladium hydroxide (moisture $c a$. 60\%, 20\% Pd, $51 \mathrm{mg}$ ) at room temperature under $\mathrm{H}_{2}$ atmosphere. The mixture was stirred at room temperature for $1.5 \mathrm{~h}$, filtered through a plug of silica gel, washed with ethyl acetate, and concentrated to afford crude compound 7 as a colorless oil which was used without further purification. Yield: $697 \mathrm{mg}$ (94\%): $[\alpha]_{\mathrm{D}}^{25}=-30.4\left(c 0.4, \mathrm{CHCl}_{3}\right) ;{ }^{1} \mathrm{H}$ NMR $(400 \mathrm{MHz}$, $\left.\mathrm{CDCl}_{3}\right) \delta 4.83(\mathrm{~d}, J=6.7 \mathrm{~Hz}, 1 \mathrm{H}), 4.69(\mathrm{~d}, J=6.7 \mathrm{~Hz}, 1 \mathrm{H}), 4.20-$ $4.13(\mathrm{~m}, 1 \mathrm{H}), 4.06-3.98(\mathrm{~m}, 3 \mathrm{H}), 3.73-3.69(\mathrm{~m}, 1 \mathrm{H}), 3.66$ (dd, $J=$ $8.1,2.8 \mathrm{~Hz}, 1 \mathrm{H}), 3.60(\mathrm{t}, J=6.6 \mathrm{~Hz}, 2 \mathrm{H}), 3.39(\mathrm{~s}, 3 \mathrm{H}), 1.59-1.42(\mathrm{~m}$, $5 \mathrm{H}), 1.40-1.25(\mathrm{~m}, 21 \mathrm{H}) ;{ }^{13} \mathrm{C}$ NMR $\left(100 \mathrm{MHz}, \mathrm{CDCl}_{3}\right) \delta 108.7$, 108.6, 98.4, 81.5, 77.3, 76.8, 76.1, 65.9, 63.1, 56.4, 33.2, 32.9, 29.8, 29.6, 29.5, 27.6, 26.8, 26.6, 26.3, 25.9, 25.4; HRMS (ESI): calcd. for $\mathrm{C}_{21} \mathrm{H}_{40} \mathrm{O}_{7} \mathrm{Na}^{+}[\mathrm{M}+\mathrm{Na}]^{+}, 427.2666$, found 427.2656.

\section{Synthesis of compound 13}

To a solution of 7 (160 mg, $0.40 \mathrm{mmol})$ in $10 \mathrm{~mL}$ of DCM was added $\mathrm{NaHCO}_{3}$ (66 mg, $0.80 \mathrm{mmol}$ ) and Dess-Martin periodinane (251 $\mathrm{mg}, 0.40 \mathrm{mmol}$ ) at $0{ }^{\circ} \mathrm{C}$. The mixture was stirred at room temperature for $0.5 \mathrm{~h}$ and quenched with saturated $\mathrm{NaHCO}_{3}$ aqueous solution. The organic phase in the resulting solution mixture was extracted with DCM ( 3 times, $50 \mathrm{~mL}$ each), dried over $\mathrm{Na}_{2} \mathrm{SO}_{4}$, filtered, and finally evaporated under a reduced pressure. The colorless oil was extracted with petroleum ether and DCM, concentrate the supernatant to afford crude aldehyde which was used without further purification.

Dimethyl-2-oxopropylphosphonate (152 mg, $119 \mu \mathrm{L}, 0.80$ mmol) was added to a suspension of $\mathrm{K}_{2} \mathrm{CO}_{3}$ (164 mg, 1.20 $\mathrm{mmol}$ ) and the crude aldehyde in $\mathrm{MeOH}(10 \mathrm{~mL})$ under $\mathrm{N}_{2}$ atmosphere. The mixture was stirred at room temperature for $4.5 \mathrm{~h}$. The blue mixture was concentrated, extracted with EtOAc, dried over $\mathrm{Na}_{2} \mathrm{SO}_{4}$, filtered, and finally evaporated under a reduced pressure. The residue was purified by chromatography on silica gel (petroleum ether/EtOAc $7: 1$ ) to afford 13 as 
a colorless oil. Yield: $119 \mathrm{mg}$ (66\% for three steps): $[\alpha]_{\mathrm{D}}^{25}=-26.4$ (c 2.0, $\left.\mathrm{CHCl}_{3}\right) ;{ }^{1} \mathrm{H} \mathrm{NMR}\left(400 \mathrm{MHz}, \mathrm{CDCl}_{3}\right) \delta 4.85(\mathrm{~d}, J=6.7 \mathrm{~Hz}$, $1 \mathrm{H}), 4.70(\mathrm{~d}, J=6.8 \mathrm{~Hz}, 1 \mathrm{H}), 4.24-4.13(\mathrm{~m}, 1 \mathrm{H}), 4.08-3.97(\mathrm{~m}$, $3 \mathrm{H}), 3.76-3.70(\mathrm{~m}, 1 \mathrm{H}), 3.68(\mathrm{dd}, J=8.0,2.8 \mathrm{~Hz}, 1 \mathrm{H}), 3.40(\mathrm{~s}$, $3 \mathrm{H}), 2.17(\mathrm{td}, J=7.0,2.6 \mathrm{~Hz}, 2 \mathrm{H}), 1.93(\mathrm{t}, J=2.6 \mathrm{~Hz}, 1 \mathrm{H}), 1.63-$ 1.45 (m, 5H), 1.43-1.24 (m, 19H); ${ }^{13} \mathrm{C} \mathrm{NMR} \mathrm{(100} \mathrm{MHz,} \mathrm{CDCl}_{3}$ ) $\delta$ 108.69, 108.66, 98.4, 84.9, 81.6, 77.3, 76.8, 76.1, 68.3, 66.0, 56.5, 33.3, 29.7, 29.2, 28.8, 28.6, 27.7, 26.8, 26.7, 26.3, 25.5, 18.6; HRMS (ESI): calcd. for $\mathrm{C}_{22} \mathrm{H}_{38} \mathrm{O}_{6} \mathrm{Na}^{+}[\mathrm{M}+\mathrm{Na}]^{+}, 421.2561$, found 421.2569 .

\section{Synthesis of compound 14a}

$n$-Butyllithium (2.5 $\mathrm{M}$ in hexanes, $0.14 \mathrm{~mL}, 0.36 \mathrm{mmol}$ ) was added dropwise to a stirred solution of terminal alkyne 13 (110 mg, $0.28 \mathrm{mmol}$ ) and HMPA (72 $\mu \mathrm{L}, 0.41 \mathrm{mmol})$ in dry THF $(10 \mathrm{~mL})$ at $-40{ }^{\circ} \mathrm{C}$. The reaction mixture was stirred at room temperature and added 1-iodo-7-methyloctane gave an orange colored solution. Quenched with saturated $\mathrm{NH}_{4} \mathrm{Cl}$ aqueous solution after $4.5 \mathrm{~h}$. The organic phase in the resulting solution mixture was extracted with EtOAc ( 3 times, $50 \mathrm{~mL}$ each), dried over $\mathrm{Na}_{2} \mathrm{SO}_{4}$, filtered, and finally evaporated under a reduced pressure. The residue was purified by chromatography on silica gel (petroleum ether/EtOAc $12: 1$ ) to afford 14a as a colorless oil. Yield: $101 \mathrm{mg}$ (70\%): $[\alpha]_{\mathrm{D}}^{25}=-20.5\left(c 0.8, \mathrm{CHCl}_{3}\right) ;{ }^{1} \mathrm{H} \mathrm{NMR}$ $\left(400 \mathrm{MHz}, \mathrm{CDCl}_{3}\right) \delta 4.84(\mathrm{~d}, J=6.6 \mathrm{~Hz}, 1 \mathrm{H}), 4.70(\mathrm{~d}, J=6.6 \mathrm{~Hz}$, $1 \mathrm{H}), 4.23-4.12(\mathrm{~m}, 1 \mathrm{H}), 4.07-3.98(\mathrm{~m}, 3 \mathrm{H}), 3.75-3.70(\mathrm{~m}, 1 \mathrm{H})$, $3.67(\mathrm{dd}, J=8.0,2.8 \mathrm{~Hz}, 1 \mathrm{H}), 3.40(\mathrm{~s}, 3 \mathrm{H}), 2.18-2.07(\mathrm{~m}, 4 \mathrm{H})$, 1.60-1.42 (m, 8H), 1.41-1.29 (m, 21H), 1.28-1.23 (m, 4H), 1.18$1.09(\mathrm{~m}, 2 \mathrm{H}), 0.85(\mathrm{~d}, J=6.6 \mathrm{~Hz}, 6 \mathrm{H}) ;{ }^{13} \mathrm{C} \mathrm{NMR}\left(100 \mathrm{MHz}, \mathrm{CDCl}_{3}\right)$ $\delta$ 108.68, 108.65, 98.4, 81.6, 80.5, 80.3, 77.4, 76.8, 76.1, 66.0, $56.4,39.2,33.3,29.8,29.6,29.4,29.3,29.3,29.1,29.0,28.1,27.7$, 27.5, 26.8, 26.7, 26.4, 25.5, 22.8, 19.0, 18.9; HRMS (ESI): calcd. for $\mathrm{C}_{31} \mathrm{H}_{56} \mathrm{O}_{6} \mathrm{Na}^{+}[\mathrm{M}+\mathrm{Na}]^{+}, 547.3969$, found 547.3969.

\section{Synthesis of compound $14 \mathrm{~b}$}

$n$-Butyllithium (2.5 $\mathrm{M}$ in hexanes, $91 \mu \mathrm{L}, 0.23 \mathrm{mmol}$ ) was added dropwise to a stirred solution of terminal alkyne 13 (70 mg, 0.18 mmol) and HMPA (46 $\mu \mathrm{L}, 0.26 \mathrm{mmol})$ in dry THF $(8 \mathrm{~mL})$ at $-40{ }^{\circ} \mathrm{C}$. The reaction mixture was stirred at room temperature and added 1-iodononane gave an orange colored solution. Quenched with saturated $\mathrm{NH}_{4} \mathrm{Cl}$ aqueous solution after $20 \mathrm{~h}$. The organic phase in the resulting solution mixture was extracted with EtOAc ( 3 times, $30 \mathrm{~mL}$ each), dried over $\mathrm{Na}_{2} \mathrm{SO}_{4}$, filtered, and finally evaporated under a reduced pressure. The residue was purified by chromatography on silica gel (petroleum ether/EtOAc $7: 1$ ) to afford 14b as a colorless oil. Yield: $67 \mathrm{mg}(75 \%):[\alpha]_{\mathrm{D}}^{25}=-18.4\left(c 1.4, \mathrm{CHCl}_{3}\right) ;{ }^{1} \mathrm{H}$ NMR $(400 \mathrm{MHz}$, $\left.\mathrm{CDCl}_{3}\right) \delta 4.85(\mathrm{~d}, J=6.7 \mathrm{~Hz}, 1 \mathrm{H}), 4.71(\mathrm{~d}, J=6.7 \mathrm{~Hz}, 1 \mathrm{H}), 4.22-$ $4.13(\mathrm{~m}, 1 \mathrm{H}), 4.11-3.91(\mathrm{~m}, 3 \mathrm{H}), 3.77-3.71(\mathrm{~m}, 1 \mathrm{H}), 3.68(\mathrm{dd}, J=$ 8.0, $2.8 \mathrm{~Hz}, 1 \mathrm{H}), 3.41(\mathrm{~s}, 3 \mathrm{H}), 2.16-2.09(\mathrm{~m}, 4 \mathrm{H}), 1.62-1.42(\mathrm{~m}$, 9H), 1.41-1.12 (m, 29H), $0.87(\mathrm{t}, J=6.6 \mathrm{~Hz}, 3 \mathrm{H}) ;{ }^{13} \mathrm{C} \mathrm{NMR}(100$ $\left.\mathrm{MHz}, \mathrm{CDCl}_{3}\right) \delta 108.70,108.66,98.4,81.6,80.5,80.3,77.4,76.9$, 76.1, 66.0, 56.5, 33.3, 32.1, 29.8, 29.7, 29.5, 29.4, 29.3, 29.1, 29.0, 27.7, 26.9, 26.7, 26.4, 25.5, 22.9, 19.0, 14.3; HRMS (ESI) calcd for $\mathrm{C}_{31} \mathrm{H}_{56} \mathrm{O}_{6} \mathrm{Na}^{+}[\mathrm{M}+\mathrm{Na}]^{+} 547.3969$, found 547.3975 .

\section{Synthesis of compound 15a}

To a solution of $14 \mathrm{a}(40 \mathrm{mg}, 0.076 \mathrm{mmol})$ in $6 \mathrm{~mL}$ of methanol and ethyl acetate was added Lindlar catalyst $(12 \mathrm{mg}, 0.023$ $\mathrm{mmol}$ ) at room temperature under $\mathrm{H}_{2}$ atmosphere. The mixture was stirred at room temperature for $1.5 \mathrm{~h}$, filtered through a plug of silica gel, washed with ethyl acetate, and concentrated to afford 15a as a colorless oil which was used without further purification. Yield: $39 \mathrm{mg}(98 \%):[\alpha]_{\mathrm{D}}^{25}=-15.0\left(c 0.8, \mathrm{CHCl}_{3}\right) ;{ }^{1} \mathrm{H}$ NMR (400 MHz, $\left.\mathrm{CDCl}_{3}\right) \delta 5.43-5.25(\mathrm{~m}, 2 \mathrm{H}), 4.84(\mathrm{~d}, J=6.8 \mathrm{~Hz}$, $1 \mathrm{H}), 4.71(\mathrm{~d}, J=6.8 \mathrm{~Hz}, 1 \mathrm{H}), 4.25-4.13(\mathrm{~m}, 1 \mathrm{H}), 4.09-3.97(\mathrm{~m}$, $3 \mathrm{H}), 3.75-3.71(\mathrm{~m}, 1 \mathrm{H}), 3.68(\mathrm{dd}, J=8.0,2.9 \mathrm{~Hz}, 1 \mathrm{H}), 3.40(\mathrm{~s}$, $3 \mathrm{H}), 2.07-1.92(\mathrm{~m}, 4 \mathrm{H}), 1.61-1.45(\mathrm{~m}, 4 \mathrm{H}), 1.43-1.22(\mathrm{~m}, 29 \mathrm{H})$, 1.20-1.09 (m, 2H), $0.85(\mathrm{~d}, J=6.7 \mathrm{~Hz}, 6 \mathrm{H}) ;{ }^{13} \mathrm{C}$ NMR $(100 \mathrm{MHz}$, $\left.\mathrm{CDCl}_{3}\right) \delta 130.1,130.0,108.7,108.6,98.4,81.6,77.4,76.1,66.0$, $56.4,39.2$, 33.3, 30.0, 29.95, 29.94, 29.90, 29.6, 29.5, 29.4, 28.2, 27.7, 27.6, 27.40, 27.39, 26.8, 26.7, 26.4, 25.5, 22.8; HRMS (ESI) calcd for $\mathrm{C}_{31} \mathrm{H}_{58} \mathrm{O}_{6} \mathrm{Na}^{+}[\mathrm{M}+\mathrm{Na}]^{+}$549.4126, found 549.4125 .

\section{Synthesis of compound $15 \mathrm{~b}$}

To a solution of $\mathbf{1 4 b}$ (300 mg, $0.59 \mathrm{mmol}$ ) in $40 \mathrm{~mL}$ of methanol and ethyl acetate was added Lindlar catalyst (30 mg, 0.059 $\mathrm{mmol}$ ) at room temperature under $\mathrm{H}_{2}$ atmosphere. The mixture was stirred at room temperature for $1.5 \mathrm{~h}$, filtered through a plug of silica gel, washed with ethyl acetate, and concentrated to afford $\mathbf{1 5 b}$ as a colorless oil which was used without further purification. Yield: $298 \mathrm{mg}(99 \%):[\alpha]_{\mathrm{D}}^{25}=-23.9\left(c 0.6, \mathrm{CHCl}_{3}\right)$; ${ }^{1} \mathrm{H}$ NMR (400 MHz, $\mathrm{CDCl}_{3}$ ) $\delta$ 5.41-5.28 (m, 2H), $4.85(\mathrm{~d}, J=$ $6.8 \mathrm{~Hz}, 1 \mathrm{H}), 4.71(\mathrm{~d}, J=6.8 \mathrm{~Hz}, 1 \mathrm{H}), 4.24-4.14(\mathrm{~m}, 1 \mathrm{H}), 4.09-3.96$ (m, 3H), 3.76-3.71 (m, 1H), $3.68(\mathrm{dd}, J=8.0,2.8 \mathrm{~Hz}, 1 \mathrm{H}), 3.40(\mathrm{~s}$, $3 \mathrm{H}), 2.09-1.88(\mathrm{~m}, 4 \mathrm{H}), 1.64-1.44(\mathrm{~m}, 3 \mathrm{H}), 1.43-1.20(\mathrm{~m}, 35 \mathrm{H})$, $0.87(\mathrm{t}, J=6.7 \mathrm{~Hz}, 3 \mathrm{H}) ;{ }^{13} \mathrm{C} \mathrm{NMR}\left(100 \mathrm{MHz}, \mathrm{CDCl}_{3}\right) \delta 130.1$, 130.0, 108.69, 108.65, 98.4, 81.6, 77.4, 76.1, 66.0, 56.5, 33.3, 32.1, $29.96,29.95,29.9,29.80,29.76,29.7,29.53,29.51,29.4,27.7$, 27.41, 27.39, 26.8, 26.7, 26.4, 25.5, 22.9, 14.3; HRMS (ESI) calcd for $\mathrm{C}_{31} \mathrm{H}_{58} \mathrm{O}_{6} \mathrm{Na}^{+}[\mathrm{M}+\mathrm{Na}]^{+}$549.4126, found 549.4128.

\section{Synthesis of compound 16a}

A solution of compound 15a (32 mg, $0.061 \mathrm{mmol}$ ) and $\mathrm{H}_{5} \mathrm{IO}_{6}$ ( $28 \mathrm{mg}, 0.12 \mathrm{mmol}$ ) in $2 \mathrm{~mL}$ EtOAc was stirred for $1 \mathrm{~h}$. The reaction mixture was filtered, and the filtrate was evaporated to afford aldehyde as an orange-red oil.

To a solution of triphenylphosphine $(127 \mathrm{mg}, 0.49 \mathrm{mmol})$ in $2 \mathrm{~mL}$ dry DCM was added carbon tetrabromide $(81 \mathrm{mg}, 0.24$ $\mathrm{mmol}$ ) at $0{ }^{\circ} \mathrm{C}$. The resulting mixture was stirred for $5 \mathrm{~min}$, and then aldehyde was added slowly via syringe. Quenched with saturated $\mathrm{NaHCO}_{3}$ aqueous solution after 2 hours. The organic phase in the resulting solution mixture was extracted with DCM (3 times, $20 \mathrm{~mL}$ each), dried over $\mathrm{Na}_{2} \mathrm{SO}_{4}$, filtered, and finally evaporated under a reduced pressure. The residue was purified by chromatography on silica gel (petroleum ether/EtOAc $20: 1$ ) to afford 16a as a colorless oil. Yield: $19 \mathrm{mg}$ (51\% for three steps): $[\alpha]_{\mathrm{D}}^{25}=-42.7\left(c 0.6, \mathrm{CHCl}_{3}\right) ;{ }^{1} \mathrm{H} \mathrm{NMR}\left(400 \mathrm{MHz}, \mathrm{CDCl}_{3}\right) \delta 6.44(\mathrm{~d}, J$ $=9.1 \mathrm{~Hz}, 1 \mathrm{H}), 5.42-5.28(\mathrm{~m}, 2 \mathrm{H}), 4.71(\mathrm{~d}, J=6.8 \mathrm{~Hz}, 1 \mathrm{H}), 4.61(\mathrm{~d}, J$ $=6.8 \mathrm{~Hz}, 1 \mathrm{H}), 4.40(\mathrm{dd}, J=9.1,5.3 \mathrm{~Hz}, 1 \mathrm{H}), 4.03-3.95(\mathrm{~m}, 1 \mathrm{H})$, $3.73(\mathrm{dd}, J=7.8,5.4 \mathrm{~Hz}, 1 \mathrm{H}), 3.40(\mathrm{~s}, 3 \mathrm{H}), 2.12-1.89(\mathrm{~m}, 4 \mathrm{H}), 1.61-$ 
$1.45(\mathrm{~m}, 4 \mathrm{H}), 1.42(\mathrm{~d}, J=1.6 \mathrm{~Hz}, 6 \mathrm{H}), 1.38-1.21(\mathrm{~m}, 17 \mathrm{H}), 1.18-$ $1.10(\mathrm{~m}, 2 \mathrm{H}), 0.86(\mathrm{~d}, J=6.6 \mathrm{~Hz}, 6 \mathrm{H}) ;{ }^{13} \mathrm{C} \mathrm{NMR}\left(100 \mathrm{MHz}, \mathrm{CDCl}_{3}\right)$ $\delta$ 135.8, 130.2, 130.0, 109.4, 94.7, 93.8, 82.1, 77.1, 76.3, 56.0, 39.3, 33.9, 30.0, 29.97, 29.96, 29.7, 29.59, 29.56, 29.4, 28.2, 27.7, 27.6, 27.43, 27.42, 26.9, 26.2, 22.9; HRMS (ESI) calcd for $\mathrm{C}_{28} \mathrm{H}_{50} \mathrm{Br}_{2} \mathrm{O}_{4} \mathrm{~K}^{+}$ $[\mathrm{M}+\mathrm{K}]^{+} 647.1707$, found 647.1713 .

\section{Synthesis of compound $16 b$}

A solution of compound $\mathbf{1 5 b}(262 \mathrm{mg}, 0.51 \mathrm{mmol})$ and $\mathrm{H}_{5} \mathrm{IO}_{6}$ (234 mg, $1.02 \mathrm{mmol}$ ) in $20 \mathrm{~mL}$ EtOAc was stirred for $1 \mathrm{~h}$. The reaction mixture was filtered, and the filtrate was evaporated to afford aldehyde as a orange red oil.

To a solution of triphenylphosphine $(1.08 \mathrm{~g}, 4.12 \mathrm{mmol})$ in $20 \mathrm{~mL}$ dry DCM was added carbon tetrabromide (680 mg, 2.06 $\mathrm{mmol}$ ) at $0{ }^{\circ} \mathrm{C}$. The resulting mixture was stirred for $5 \mathrm{~min}$, and then aldehyde was added slowly via syringe. Quenched with saturated $\mathrm{NaHCO}_{3}$ aqueous solution after 2 hours. The organic phase in the resulting solution mixture was extracted with DCM (3 times, $100 \mathrm{~mL}$ each), dried over $\mathrm{Na}_{2} \mathrm{SO}_{4}$, filtered, and finally evaporated under a reduced pressure. The residue was purified by chromatography on silica gel (petroleum ether/EtOAc $20: 1$ ) to afford 16b as a colorless oil. Yield: $166 \mathrm{mg}$ (52\% for three steps): $[\alpha]_{\mathrm{D}}^{25}=-64.9\left(c 0.2, \mathrm{CHCl}_{3}\right) ;{ }^{1} \mathrm{H}$ NMR (400 $\mathrm{MHz}, \mathrm{CDCl}_{3}$ ) $\delta 6.44(\mathrm{~d}, J=9.0 \mathrm{~Hz}, 1 \mathrm{H}), 5.49-5.27(\mathrm{~m}, 2 \mathrm{H}), 4.71(\mathrm{~d}, J=6.8 \mathrm{~Hz}$, $1 \mathrm{H}), 4.61(\mathrm{~d}, J=6.8 \mathrm{~Hz}, 1 \mathrm{H}), 4.40(\mathrm{dd}, J=9.1,5.3 \mathrm{~Hz}, 1 \mathrm{H}), 4.04-$ $3.91(\mathrm{~m}, 1 \mathrm{H}), 3.72(\mathrm{dd}, J=7.8,5.3 \mathrm{~Hz}, 1 \mathrm{H}), 3.40(\mathrm{~s}, 3 \mathrm{H}), 2.16-$ $1.85(\mathrm{~m}, 4 \mathrm{H}), 1.65-1.45(\mathrm{~m}, 3 \mathrm{H}), 1.44-1.18(\mathrm{~m}, 29 \mathrm{H}), 0.87(\mathrm{t}, J=$ $6.7 \mathrm{~Hz}, 3 \mathrm{H}) ;{ }^{13} \mathrm{C} \mathrm{NMR}\left(100 \mathrm{MHz}, \mathrm{CDCl}_{3}\right) \delta 135.7,130.1,130.0$, 109.4, 94.6, 93.8, 82.0, 77.1, 76.2, 56.0, 33.9, 32.1, 30.0, 29.9, 29.81, 29.76, 29.7, 29.6, 29.54, 29.51, 29.4, 27.7, 27.4, 26.9, 26.2, 22.9, 14.3; HRMS (ESI) calcd for $\mathrm{C}_{28} \mathrm{H}_{50} \mathrm{Br}_{2} \mathrm{O}_{4} \mathrm{~K}^{+}[\mathrm{M}+\mathrm{K}]^{+}$ 647.1707, found 647.1710.

\section{Synthesis of compound $17 \mathrm{a}$}

To a stirred solution of the dibromoalkene 16a $(65 \mathrm{mg}, 0.10$ $\mathrm{mmol}$ ) in $6 \mathrm{~mL}$ anhydrous THF was added $60 \%$ sodium hydride (42 mg, $1.05 \mathrm{mmol}$ ) as a solid at $0{ }^{\circ} \mathrm{C}$. The resulting mixture was warmed to room temperature, added two drops of water slowly and stirred overnight. After the reaction mixture was quenched with saturated aq. $\mathrm{NH}_{4} \mathrm{Cl}$, it was extracted with EtOAc. The combined organic layers were dried over $\mathrm{Na}_{2} \mathrm{SO}_{4}$, filtered, and finally evaporated under a reduced pressure to give the crude 1bromoalkyne $\mathbf{6 a}$, which was used for the next reaction without further purification.

To a stirred aqueous solution of $30 \% n-\mathrm{BuNH}_{4}(4 \mathrm{~mL})$ was added crystal $\mathrm{CuCl}$ at room temperature, resulted in the formation of a blue solution immediately. A few crystals of hydroxylamine hydrochloride were added until the blue color disappeared. The resulting colorless solution indicated the present of $\mathrm{Cu}(\mathrm{I})$ salt. A solution of propargyl alcohol $(0.12 \mathrm{~mL}$, $2.09 \mathrm{mmol})$ in $\mathrm{Et}_{2} \mathrm{O}(0.5 \mathrm{~mL})$ was added to the solution at room temperature, yielding a yellow acetylide suspension, which was immediately cooled to $0{ }^{\circ} \mathrm{C}$. A solution of 1-bromoalkyne $6 \mathrm{a}$ in $\mathrm{Et}_{2} \mathrm{O}(0.5 \mathrm{~mL})$ was added dropwise. The resulting mixture was warmed to room temperature and stirred for $4 \mathrm{~h}$. More crystals of hydroxylamine hydrochloride were added throughout the reaction to prevent the reaction mixture from turning blue or green. The reaction mixture was extracted with EtOAc. The combined organic layers were dried over $\mathrm{Na}_{2} \mathrm{SO}_{4}$, filtered, and finally evaporated under a reduced pressure. The residue was purified by chromatography on silica gel (petroleum ether/ EtOAc $6: 1)$ to afford 17a as a colorless oil. Yield: $37 \mathrm{mg}(69 \%$ for two steps): $[\alpha]_{\mathrm{D}}^{25}=-79.5\left(c 0.4, \mathrm{CHCl}_{3}\right) ;{ }^{1} \mathrm{H} \mathrm{NMR}(400 \mathrm{MHz}$, $\left.\mathrm{CDCl}_{3}\right) \delta 5.45-5.29(\mathrm{~m}, 2 \mathrm{H}), 4.92(\mathrm{~d}, J=6.8 \mathrm{~Hz}, 1 \mathrm{H}), 4.64(\mathrm{~d}, J=$ $6.8 \mathrm{~Hz}, 1 \mathrm{H}), 4.52(\mathrm{~d}, J=6.3 \mathrm{~Hz}, 1 \mathrm{H}), 4.34(\mathrm{~s}, 2 \mathrm{H}), 4.03(\mathrm{td}, J=7.9$, $3.2 \mathrm{~Hz}, 1 \mathrm{H}), 3.80(\mathrm{t}, J=6.9 \mathrm{~Hz}, 1 \mathrm{H}), 3.40(\mathrm{~s}, 3 \mathrm{H}), 2.09-1.85(\mathrm{~m}$, $4 \mathrm{H}), 1.82-1.68(\mathrm{~m}, 1 \mathrm{H}), 1.63-1.46(\mathrm{~m}, 5 \mathrm{H}), 1.45-1.22(\mathrm{~m}, 21 \mathrm{H})$, 1.21-1.10 (m, 2H), $0.86(\mathrm{~d}, J=6.5 \mathrm{~Hz}, 6 \mathrm{H}) ;{ }^{13} \mathrm{C}$ NMR $(100 \mathrm{MHz}$, $\left.\mathrm{CDCl}_{3}\right) \delta 130.2,130.0,109.7,94.5,81.6,78.6,77.7,75.4,71.5$, 69.8, 67.7, 56.0, 51.6, 39.2, 34.2, 30.01, 29.99, 29.97, 29.7, 29.62, 29.56, 29.5, 28.2, 27.8, 27.6, 27.4, 27.2, 26.1, 22.9; HRMS m/z (ESI) calcd for $\mathrm{C}_{31} \mathrm{H}_{53} \mathrm{O}_{5}{ }^{+}[\mathrm{M}+\mathrm{H}]^{+}$505.3888, found 505.3877.

\section{Synthesis of compound $17 \mathrm{~b}$}

To a stirred solution of dibromoalkene $16 \mathrm{~b}(110 \mathrm{mg}, 0.18 \mathrm{mmol})$ in $20 \mathrm{~mL}$ anhydrous THF was added $60 \%$ sodium hydride (211 $\mathrm{mg}, 3.53 \mathrm{mmol}$ ) as a solid at $0{ }^{\circ} \mathrm{C}$. The resulting mixture was warmed to room temperature, added two drops of water slowly and stirred overnight. After the reaction mixture was quenched with saturated aq. $\mathrm{NH}_{4} \mathrm{Cl}$, it was extracted with EtOAc. The combined organic layers were dried over $\mathrm{Na}_{2} \mathrm{SO}_{4}$, filtered, and finally evaporated under a reduced pressure to give the crude 1-bromoalkyne $\mathbf{6 b}$, which was used for the next reaction without further purification.

To a stirred $30 \% n-\mathrm{BuNH}_{4}$ aqueous solution $(6 \mathrm{~mL})$ was added crystal of $\mathrm{CuCl}$ at room temperature, resulted in the formation of a blue solution immediately. A few crystal of hydroxylamine hydrochloride were added until the blue color disappeared. The resulting colorless solution indicated the present of $\mathrm{Cu}(\mathrm{I})$ salt. A solution of propargyl alcohol $(0.17 \mathrm{~mL}$, $3.53 \mathrm{mmol})$ in $\mathrm{Et}_{2} \mathrm{O}(0.5 \mathrm{~mL})$ was added to the solution at room temperature, yielding a yellow acetylide suspension, which was immediately cooled to $0{ }^{\circ} \mathrm{C}$. A solution of 1-bromoalkyne $6 \mathbf{b}$ in $\mathrm{Et}_{2} \mathrm{O}(0.5 \mathrm{~mL})$ was added dropwise. The resulting mixture was warmed to room temperature and stirred for $4 \mathrm{~h}$. More crystals of hydroxylamine hydrochloride were added throughout the reaction to prevent the reaction mixture from turning blue or green. The reaction mixture was extracted with EtOAc. The combined organic layers were dried over $\mathrm{Na}_{2} \mathrm{SO}_{4}$, filtered, and finally evaporated under a reduced pressure. The residue was purified by chromatography on silica gel (petroleum ether/ EtOAc $6: 1)$ to afford $17 \mathbf{b}$ as a colorless oil. Yield: $53 \mathrm{mg}(58 \%$ for two steps): $[\alpha]_{\mathrm{D}}^{25}=-114.0\left(c 0.2, \mathrm{CHCl}_{3}\right) ;{ }^{1} \mathrm{H} \mathrm{NMR}(400 \mathrm{MHz}$, $\left.\mathrm{CDCl}_{3}\right) \delta 5.45-5.27(\mathrm{~m}, 2 \mathrm{H}), 4.92(\mathrm{~d}, J=6.8 \mathrm{~Hz}, 1 \mathrm{H}), 4.64(\mathrm{~d}, J=$ $6.8 \mathrm{~Hz}, 1 \mathrm{H}), 4.52(\mathrm{~d}, J=6.3 \mathrm{~Hz}, 1 \mathrm{H}), 4.33(\mathrm{~s}, 2 \mathrm{H}), 4.03(\mathrm{td}, J=7.9$, $3.3 \mathrm{~Hz}, 1 \mathrm{H}), 3.79$ (dd, $J=7.4,6.4 \mathrm{~Hz}, 1 \mathrm{H}), 3.39$ (s, 3H), 2.12-1.87 $(\mathrm{m}, 4 \mathrm{H}), 1.83-1.68(\mathrm{~m}, 2 \mathrm{H}), 1.65-1.46(\mathrm{~m}, 2 \mathrm{H}), 1.44-1.23(\mathrm{~m}$, $28 \mathrm{H}), 0.93-0.82(\mathrm{~d}, J=6.8 \mathrm{~Hz}, 3 \mathrm{H}) ;{ }^{13} \mathrm{C} \mathrm{NMR}\left(100 \mathrm{MHz}, \mathrm{CDCl}_{3}\right)$ $\delta$ 130.2 , 130.0, 109.7, 94.5, 81.6, 78.5, 77.7, 75.3, 71.5, 69.7, 67.7, 56.0, 51.6, 34.2 , 32.1, 29.97, 29.95, 29.80, 29.75, 29.7, 29.6, 29.53, 29.51, 29.45, 27.8, 27.4, 27.1, 26.1, 22.9, 14.3; HRMS $m / z$ (ESI) calcd for $\mathrm{C}_{31} \mathrm{H}_{52} \mathrm{O}_{5} \mathrm{Na}^{+}[\mathrm{M}+\mathrm{Na}]^{+}$527.3707, found 527.3706. 


\section{Synthesis of petrosiol B (2)}

To a stirred solution of diyne 17a (25 mg, $0.048 \mathrm{mmol})$ in $3 \mathrm{~mL}$ EtOH was added $3 \mathrm{~N} \mathrm{HCl}(0.5 \mathrm{~mL})$ aqueous solution at room temperature. The mixture was stirred at $70{ }^{\circ} \mathrm{C}$ for $1.5 \mathrm{~h}$. The reaction mixture was cooled to room temperature and evaporated under a reduced pressure to afford 2 as a white powder. Yield: $20 \mathrm{mg}$ (98\%): $[\alpha]_{\mathrm{D}}^{25}=-4.2(c 0.25, \mathrm{MeOH}) ;{ }^{1} \mathrm{H}$ NMR $(400 \mathrm{MHz}$, $\left.\mathrm{CDCl}_{3} / \mathrm{MeOD}=4: 1\right) \delta 5.45-5.27(\mathrm{~m}, 2 \mathrm{H}), 4.46(\mathrm{~d}, J=6.9 \mathrm{~Hz}, 1 \mathrm{H})$, $4.27(\mathrm{~s}, 2 \mathrm{H}), 3.82-3.68(\mathrm{~m}, 1 \mathrm{H}), 3.44(\mathrm{dd}, J=6.9,2.2 \mathrm{~Hz}, 1 \mathrm{H}), 2.13-$ $1.88(\mathrm{~m}, 4 \mathrm{H}), 1.69-1.40(\mathrm{~m}, 4 \mathrm{H}), 1.38-1.23$ (m, 17H), 1.21-1.09 (m, $2 \mathrm{H}), 0.87$ (d, $J=6.6 \mathrm{~Hz}, 6 \mathrm{H}) ;{ }^{1} \mathrm{H}$ NMR (400 MHz, MeOD) $\delta 5.46-$ $5.26(\mathrm{~m}, 2 \mathrm{H}), 4.43(\mathrm{~d}, J=7.6 \mathrm{~Hz}, 1 \mathrm{H}), 4.24(\mathrm{~s}, 2 \mathrm{H}), 3.83-3.67(\mathrm{~m}$, $1 \mathrm{H}), 3.37$ (dd, $J=7.6,2.3 \mathrm{~Hz}, 1 \mathrm{H}), 2.14-1.91$ (m, 4H), 1.66-1.45 $(\mathrm{m}, 4 \mathrm{H}), 1.41-1.24(\mathrm{~m}, 17 \mathrm{H}), 1.23-1.13(\mathrm{~m}, 2 \mathrm{H}), 0.89(\mathrm{~d}, J=6.6 \mathrm{~Hz}$, $6 \mathrm{H}) ;{ }^{13} \mathrm{C} \mathrm{NMR}\left(100 \mathrm{MHz}, \mathrm{CDCl}_{3} / \mathrm{MeOD}=4: 1\right) \delta$ 130.2, 130.1, 78.4, 77.6, 76.2, 71.3, 70.2, 69.0, 64.5, 50.7, 39.3, 34.3, 30.07, 30.06, 30.0, 29.9, 29.8, 29.59, 29.58, 28.2, 27.6, 27.47, 27.46, 26.0, 22.8; ${ }^{13} \mathrm{C}$ NMR (100 MHz, MeOD) $\delta 130.9,130.8,79.3,79.2,77.7,72.1$, 70.6, 69.4, 65.4, 51.0, 40.2, 35.0, 30.9, 30.84, 30.77, 30.7, 30.39, 30.35, 29.2, 28.5, 28.2, 28.1, 26.9, 23.1; HRMS (ESI) calcd for $\mathrm{C}_{26} \mathrm{H}_{44} \mathrm{O}_{4} \mathrm{~K}^{+}[\mathrm{M}+\mathrm{K}]^{+}$459.2871, found 459.2865.

\section{Synthesis of petrosiol D (4)}

To a stirred solution of diyne $17 \mathbf{b}(19 \mathrm{mg}, 0.037 \mathrm{mmol})$ in $4 \mathrm{~mL}$ EtOH was added $3 \mathrm{~N} \mathrm{HCl}(0.6 \mathrm{~mL})$ aqueous solution at room temperature. The mixture was stirred at $70{ }^{\circ} \mathrm{C}$ for $2 \mathrm{~h}$. The reaction mixture was cooled to room temperature and evaporated under a reduced pressure to afford $\mathbf{4}$ as a white powder. Yield: $15 \mathrm{mg}$ (98\%): $[\alpha]_{\mathrm{D}}^{25}=-4.8(c 0.18, \mathrm{MeOH}) ;{ }^{1} \mathrm{H}$ NMR $(400$ $\left.\mathrm{MHz}, \mathrm{CDCl}_{3} / \mathrm{MeOD}=4: 1\right) \delta 5.44-5.27(\mathrm{~m}, 2 \mathrm{H}), 4.46(\mathrm{~d}, J=$ $6.7 \mathrm{~Hz}, 1 \mathrm{H}), 4.27(\mathrm{~s}, 2 \mathrm{H}), 3.82-3.71(\mathrm{~m}, 1 \mathrm{H}), 3.45(\mathrm{~d}, J=6.3 \mathrm{~Hz}$, $1 \mathrm{H}), 2.08-1.92(\mathrm{~m}, 4 \mathrm{H}), 1.68-1.42(\mathrm{~m}, 3 \mathrm{H}), 1.37-1.18(\mathrm{~m}, 23 \mathrm{H})$, 0.93-0.82 (d, $J=6.7 \mathrm{~Hz}, 3 \mathrm{H}) ;{ }^{1} \mathrm{H}$ NMR (400 MHz, MeOD) $\delta 5.55-$ $5.25(\mathrm{~m}, 2 \mathrm{H}), 4.44(\mathrm{~d}, J=7.6 \mathrm{~Hz}, 1 \mathrm{H}), 4.24(\mathrm{~s}, 2 \mathrm{H}), 3.82-3.70(\mathrm{~m}$, $1 \mathrm{H}), 3.38$ (dd, $J=7.6,2.3 \mathrm{~Hz}, 1 \mathrm{H}), 2.14-1.93(\mathrm{~m}, 4 \mathrm{H}), 1.67-1.42$ (m, 3H), 1.41-1.24 (m, 23H), 0.95-0.85 (d, $J=6.7 \mathrm{~Hz}, 3 \mathrm{H}) ;{ }^{13} \mathrm{C}$ NMR (100 MHz, $\left.\mathrm{CDCl}_{3} / \mathrm{MeOD}=4: 1\right) \delta 130.1,130.0,78.3,77.6$, $76.1,71.3,70.1,68.9,64.4,50.6,34.2,32.1,30.0,29.9,29.81$, $29.76,29.7,29.50,29.47,29.46,27.37,27.35,25.9,22.8,14.2 ;{ }^{13} \mathrm{C}$ NMR (100 MHz, MeOD) $\delta 130.8$ (2C), 79.3, 79.2, 77.6, 72.1, 70.6, 69.4, 65.3, 51.0, 35.0, 33.1, 30.9, 30.83, 30.75, 30.73, 30.65, 30.6, 30.5, 30.4, 30.3, 28.2, 28.1, 26.9, 23.8, 14.5; HRMS (ESI) calcd for $\mathrm{C}_{26} \mathrm{H}_{44} \mathrm{O}_{4} \mathrm{Na}^{+}[\mathrm{M}+\mathrm{Na}]^{+}$443.3132, found 443.3134.

\section{Bioactivity section}

PC12 cell culture and neuronal differentiation. PC12 cell was obtained from the Shanghai Cell Bank of Type Culture Collection of Chinese Academy of Science. Cells were maintained in DMEM (Gibco, Life Technologies) containing 6\% (v/v) fetal bovine serum (FBS, Gibco, Life Technologies), 6\% (v/v) horse serum (HS, Gibco, Life Technologies) and $100 \mathrm{U} \mathrm{mL}^{-1}$ penicillin-streptomycin (Gibco, Life Technologies). Cells were incubated under a humidified atmosphere of $95 \% \mathrm{O}_{2}$ and $5 \%$ $\mathrm{CO}_{2}$ at $37{ }^{\circ} \mathrm{C}$. For differentiation experiments, PC12 cells were cultured in differentiation medium: DMEM medium with $1 \%$
HS, $1 \% \mathrm{FBS}$, and $100 \mathrm{U} \mathrm{mL}^{-1}$ penicillin-streptomycin. Petrosiol $\mathrm{B}, \mathrm{D}$ and $\mathrm{E}$ were dissolved in dimethyl sulfoxide (DMSO, Amresco). The medium was replaced by a differentiation medium containing $0.1 \%$ DMSO and the compounds (petrosiol $\mathrm{B}, \mathrm{D}$ and $\mathrm{E}$ at the indicated concentrations) when the cells reached $20-30 \%$ confluency. We previously proved that petrosiol E, under $5 \mu \mathrm{g} \mathrm{mL}{ }^{-1}$, induced the differentiation of PC12 by enhancing Nrf2 activity, thus we used petrosiol $\mathrm{E}$ as positive control in this study. Medium containing 0.1\% DMSO did not elicit any toxicity to cells or change the ability of cell differentiation. Thus, medium containing $0.1 \%$ DMSO served as the vehicle control in this paper.

Cell viability assay. Cell viability was determined through the CCK-8 assay (CCK8, Dojindo Laboratories). First, PC12 cells were seeded in 96-well plates with $6 \times 10^{3}$ per well overnight. Then, cells were cultured in differentiation medium containing petrosiol $\mathrm{B}, \mathrm{D}$ and $\mathrm{E}$ at various concentrations for 1, 3 and 5 days, followed by the addition of $10 \mu \mathrm{L}$ CCK-8 solution for $1 \mathrm{~h}$. The absorbance of each well was measured at $450 \mathrm{~nm}$ using a microplate reader (Synergy 2, BioTek).

Assessment of neurite bearing cells. Neurite outgrowth was evaluated by the percentage of neurite-bearing cells. Morphological changes of PC12 cells were observed and photographed using EVOS XL Core Imaging System (Life Technologies) at different treated time. The cells were defined as neurite bearing cells when their neurites were $>2$ cell-body in length. In this study, $\approx 500$ cells were screened in six randomly fields in each well. Lastly, the percentage of neurite-bearing cells was calculated by normalizing to the total number of cells in each field.

RNA extraction and qRT-PCR analysis. Total RNAs were extracted from cells using RNA extraction kit (BioTeke) and reverse transcribed into cDNA (TransGen). Quantitative reverse transcription polymerase chain reaction (qRT-PCR) was performed using SYBR Green PCR mix (Roche) with specific primers. The relative signal intensity was measured using a Real-Time PCR Detection System (ABI 7500). The primers used in the study were as follows: Rat HO-1 (forward, 5'TGCTCGCATGAACACTCTG-3' ${ }^{\prime}$; reverse, $5^{\prime}$-TCCTCTGTCAGCAGTGCCT-3'); Rat Gapdh (forward, 5'-AACCTGCCAAGTATGATGAC-3'; reverse, 5'-GGAGTTGCTGTTGAAGTCA-3'). Values were normalized against that of the housekeeping gene glyceraldehyde 3-phosphate dehydrogenase (Gapdh). Relative transcript expression was determined using a control sample as a calibrator and the $\Delta \Delta C_{t}$ method. Data were presented as fold change relative to the vehicle control group.

Western blotting analysis. Cells after treatment were washed twice with PBS and nuclear proteins were extracted from cells using nuclear protein extraction kit (Solarbio). Then, equal amounts of proteins were subjected to $8-12 \%$ SDS-PAGE and western blot analysis. The primary antibodies used in this study: anti-Nrf2 Ab (16396-1-AP, 1 : 1000; Proteintech) and antiLamin A + C (ab169532, 1 : 5000; Abcam). Anti-Lamin A + C antibodies were used for equal loading of nuclear proteins.

Statistical analysis. Results are expressed as means \pm SD of three independent experiments, unless otherwise specified. Significant differences were evaluated using one-way analysis of 
covariance (ANOVA) for multiple treatment groups. Values at $P<$ 0.05 were considered significant.

\section{Conflicts of interest}

There are no conflicts to declare.

\section{Acknowledgements}

This work was supported by the National Key Research and Development Program of China (2015CB931903 and 2016YFA0203102) and Natural Science Foundation of China (Projects 21672255 and 21621064). We thank Xinyi Zhang and Miao Chen for HRMS measurements.

\section{Notes and references}

1 (a) Z. Zhou, M. Menna, Y. Cai and Y. Guo, Chem. Rev., 2015, 115, 1543-1596; (b) R. Negri, Fitoterapia, 2015, 106, 92-109.

2 R. E. Minto and B. J. Blacklock, Prog. Lipid Res., 2008, 47, 233-306.

3 U. Wittstock, K.-H. Lichtnow and E. Teuscher, Planta Med., 1997, 63, 120-124.

4 K. Xu, J. Jiang, Z. Feng, Y. Yang, L. Li, C. Zang and P. Zhang, J. Nat. Prod., 2016, 79, 1567-1575.

5 (a) N. Panthama, S. Kanokmedhakul and K. Kanokmedhakul, J. Nat. Prod., 2010, 73, 1366-1369; (b) T. K. Kuilya and R. K. Goswami, Org. Biomol. Chem., 2016, 14, 8789-8799.

6 (a) K. Watanabe, Y. Tsuda, Y. Yamane, H. Takahashi, K. Iguchi, H. Naoki, T. Fujita and R. W. M. Van Soest, Tetrahedron Lett., 2000, 41, 9271-9276; (b) K. Watanabe, Y. Tsuda, M. Hamada, M. Omori, G. Mori, K. Iguchi, H. Naoki, T. Fujita and R. W. M. Van Soest, J. Nat. Prod., 2005, 68, 1001-1005.

7 (a) B. Zhang, Y. Wang, S. P. Yang, Y. Zhou, W. B. Wu, W. Tang, J. P. Zuo, Y. Li and J. M. Yue, J. Am. Chem. Soc., 2012, 134, 20605-20608; (b) Y. Wang, Q. F. Liu, J. J. Xue, Y. Zhou, H. C. Yu, S. P. Yang, B. Zhang, J. P. Zuo, Y. Li and J. M. Yue, Org. Lett., 2014, 16, 2062-2065.

8 C. M. Yao and X. W. Yang, J. Ethnopharmacol., 2014, 151, 791-799.

9 (a) K. Horikawa, T. Yagyu, Y. Yoshioka, T. Fujiwara, A. Kanamoto, T. Okamoto and M. Ojika, Tetrahedron, 2013, 69, 101-106; (b) B. K. Choi, B. Y. Cha, T. Yagyu, J. T. Woo and M. Ojika, Bioorg. Med. Chem., 2013, 21, 1804-1810.

10 A. Sathish Reddy and P. Srihari, Tetrahedron Lett., 2013, 54, 6370-6372.
11 P. Gangadhar, A. Sathish Reddy and P. Srihari, Tetrahedron, 2016, 72, 5807-5817.

12 L. Wang, X. Zhang, J. Liu and Y. Du, Tetrahedron, 2014, 70, 8231-8235.

13 J. Liu, L. Wang, Y. Du and S. Liu, Adv. Sci., 2017, 4, 1700089. 14 F. Dolhem, C. Lievre and G. Demailly, Tetrahedron, 2003, 59, 155-164.

15 G. Pandey, K. C. Bharadwaj, M. I. Khan, K. S. Shashidhara and V. G. Puranik, Org. Biomol. Chem., 2008, 6, 2587-2595.

16 J. K. Chahal, D. Craig, C. A. Smethurst and A. J. P. White, ARKIVOC, 2011, 4, 127-139.

17 (a) K. M. Pietrusiewicz and J. Monkiewicz, J. Org. Chem., 1983, 48, 788-790; (b) K. M. Pietrusiewicz and J. Monkiewicz, Tetrahedron Lett., 1986, 27, 739-742.

18 (a) G. V. M. Sharma, T. R. Prasad, P. R. Krishna, K. Krishnudu, M. R. Rao and A. C. Kunwar, Tetrahedron: Asymmetry, 2000, 11, 4499-4507; (b) G. V. M. Sharma, A. S. Chander, P. R. Krishna, K. Krishnudu, M. R. Rao and A. C. Kunwar, Tetrahedron: Asymmetry, 2000, 11, 2643-2646. 19 (a) D. B. Dess and J. C. Martin, J. Am. Chem. Soc., 1991, 113, 7277-7287; (b) Y. G. Gao, J. Liu, L. L. Wang, M. Xiao and Y. G. Du, Eur. J. Org. Chem., 2014, 10, 2092-2098.

20 (a) S. Müller, B. Liepold, G. J. Roth and H. J. Bestmann, Synlett, 1996, 6, 521-522; (b) M. V. Mijangos and L. D. Miranda, Org. Biomol. Chem., 2018, 16, 9409-9419.

21 (a) S. Moura, C. Thomassigny, C. Ligeour, C. Greck, D. Joseph, E. Drège and F. Dumas, Green Chem., 2011, 13, 1812-1818; (b) F. Sartillo-Piscil, M. Vargas, C. Anaya de Parrodi and L. Quintero, Tetrahedron Lett., 2003, 44, 39193921.

22 (a) E. J. Corey and P. L. Fuchs, Tetrahedron Lett., 1972, 13, 3769-3772; (b) P. Michel, D. Gennet and A. Rassat, Tetrahedron Lett., 1999, 40, 8575-8578.

23 (a) D. Grandjean, P. Pale and J. Chuche, Tetrahedron Lett., 1994, 35, 3529-3530; (b) T. Durand-Reville, L. B. Gobbi, B. L. Gray, S. V. Ley and J. S. Scott, Org. Lett., 2002, 4, 3847-3850.

24 (a) K. S. Sindhu, A. P. Thankachan, P. S. Sajitha and G. Anilkumar, Org. Biomol. Chem., 2015, 13, 6891-6905; (b) J. P. Marino and H. N. Nguyen, J. Org. Chem., 2002, 67, 6841-6844.

25 A. Loboda, M. Damulewicz, E. Pyza, A. Jozkowicz and J. Dulak, Cell. Mol. Life Sci., 2016, 73, 3221-3247.

26 K. Xu, P. Yang, Y. Yang, Z. Feng, J. Jiang and P. Zhang, Org. Lett., 2017, 19, 686-689. 